\title{
Comprehensive characterization of the chemical constituents in Yiganmingmu oral liquid and the absorbed prototypes in cynomolgus monkey plasma after oral administration by UPLC-Q-TOF-MS based on the self built components database
}

\author{
wei wei \\ Siwei Li \\ GuangXi University of Chinese Medicine \\ Linyou Cheng \\ Guangxi Hebebiz biotecnology Co.Ltd. \\ Erwei Hao \\ GuangXi University of Chinese Medicine \\ Xiaotao Hou \\ GuangXi University of Chinese Medicine \\ Hua Zhou \\ Guangxi hebebiz biotecnology Co.Ltd. \\ Jiagang Deng ( $\square$ dengjg53@126.com ) \\ Xinsheng Yao \\ Jinan University
}

GuangXi University of Chinese Medicine https://orcid.org/0000-0003-3041-7432

\section{Research}

Keywords: Yiganmingmu oral liquid, UPLC-Q-TOF-MS, Self built database, Chemical profile, Cynomolgus monkey

Posted Date: March 2nd, 2021

DOI: https://doi.org/10.21203/rs.3.rs-254037/v1

License: (c) (1) This work is licensed under a Creative Commons Attribution 4.0 International License. Read Full License 


\section{Abstract}

Background: Yiganmingmu oral liquid (YGMM), a well known over-the-counter (OTC) drug in China, is composed of 12 types of valuable herbal medicines and has been widely used in clinical for the treatment of soreness and weakness of waist and knees, dizziness, memory loss, and fatigue. However, the chemical compositions of YGMM and its absorbed compounds in plasma remain unclear.

Methods: Since chemical investigation is the first important step to reveal effects and action mechanisms of traditional Chinese medicine (TCM), in this study, based on the self built components database, systematic characterization of the chemical profile of YGMM in vivo was carried out by using a reliable UPLC-Q-TOF-MS method. Moreover, to obtain better understanding of the absorbed prototypes in plasma, serum pharmacochemistry analysis of YGMM after oral administration was conducted by using cynomolgus monkeys as animal model.

Results: A total of 667 constituents from the 12 single herbal medicines were collected in the self built components database by searching the reported literatures, and 415 of them were initially screened as candidate compounds in YGMM by comparison of their experimental accurate mass measurements with those theoretical values. After that, 117 compounds including 17 phenolic acids, 25 flavonoids, 4 alkaloids, 10 phthalides, 5 monoterpenes, 8 triterpenoid saponins, 9 anthraquinones, and 39 other compounds, were unambiguously identified or tentatively characterized by analysing their MS/MS fragmentation patterns, and also by comparison with reference standards and those data reported in the literatures. 61 prototypes absorbed in plasma of cynomolgus monkey, including 13 phenolic acids, 21 flavonoids, 8 phthalides, 3 monoterpenes, 4 triterpenoid saponins, and 12 other compounds were tentatively assigned by serum pharmacochemistry analysis after oral administration.

Conclusion: It was the first comprehensive analysis of chemical constituents of YGMM and prototypes in plasma, and the data analysis strategy developed in this study showed high efficiency in the structural elucidations. The results might provide scientific evidence for further research on material basis of YGMM.

\section{Background}

Traditional Chinese medicine (TCM) prescriptions has long been used in the treatment of complex and chronic diseases in China due to their high efficiency but relatively low toxicity[1]. According to the wholesome thought of Chinese medicine theory, TCM prescriptions collectively exerts therapeutic effects via multi-target by complex interactions among the complicated composition systems formed by different single herbal medicines in the prescription[2]. The inefficiency in the material foundation study of TCM has seriously restricted its development and modernization. In recent years, the combination of chemical component investigation in vitro and serum pharmacochemistry analysis in vivo has been widely accepted as an effective strategy to obtain a better understanding of the potential therapeutic material basis of TCM[3, 4]. In which, ultra-high-performance liquid chromatography quadrupole time of flight mass spectrometry (UPLC-Q-TOF-MS) was considered the most powerful analytical tool for chemical components characterization of TCM and biosamples, due to its high speed, wide measurable mass range, high ratio of resolution, and capacity for simultaneous qualitative analysis[5].

Yiganmingmu oral liquid (YGMM), a well known TCM prescription, is an over-the-counter (OTC) drug registered and approved by CFDA (Approval No. B20050056) for treating soreness and weakness of waist and knees, dizziness, memory loss, and fatigue[6]. On the basis of the two classical TCM formulas[7], Siwu Tangand Gugen Tang created by a famous doctor named Shiduo Chen in Qing dynasty, the medicinal herbs contained in the prescription of YGMM was extended to 12 flavors including Rehmannia glutinosa (RG, Shudihuang), Angelica sinensis (AS, Danggui), Paeonia lactiflora Pall (PL, Baisao), Polygonatum odoratum (PO, Yuzhu), Ophiopogon japonicas (OJ, Maidong), Chrysanthemum morifolium (CM, Juhua), Ligusticum chuanxiong (LC, Chuanxiong), Anemone altaica (AA, Jiujiechangpu), Citrus reticulate (CR, Chenpi), Cassiae semen (CS, Juemingzi), Lycii fructus (LF, Gouqizi), and Bupleuri radix (BR, Chaihu). Recently our research showed that YGMM possessed good hepatoprotective activity on isoniazid-rifampicin induced liver injuries in rats[6]. However, the pharmacodynamic material basis of YGMM is still unclear. Compared to the other animal models used in experiments, cynomolgus monkey is a more useful preclinical model due to their nonhuman primates and are more similar to humans in genetics and pathophysiology, and have been applied recently for the serum pharmacochemistry analysis of Yizhi Granule[8] by our group. In the present study, we established a comprehensive data analysis strategy for the chemical components identification of YGMM and the absorbed prototypical ingredients in the plasma of cynomolgus monkey after oral administration for the first time. The self built components database was helpful to enhance the efficiency of constituents characterization (Fig.1), thus, a self built components database containing the reported chemical components of each individual medicinal herbs[9-47] of YGMM was used for the rapid screening and identification of chemical components in vitro and prototypes in vivo. This study might provide an useful analytical strategy for elucidating the material basis of YGMM and a promising experimental data for its material basis and quality control studies.

\section{Materials And Methods}




\section{Chemicals and materials}

YGMM were provided by Guangxi Hebabiz Pharmaceutical Co., Ltd. (Lot No. 130418). 16 reference standards (purity ${ }^{395 \%)}$ including ZLigustilide, senkyunolide $H$, senkyunolide I, vanillic acid, gallic acid, 3-O-feruloylquinic acid, isochlorogenic acid A, kaempferitrin, mudanpioside $\mathrm{D}$, cassiaside B2, ophiopogonin $\mathrm{D}$, hesperetin, naringin, rutin, quercetin, and ophiopogonanoe B were all purchased from Chengdu Biopurify Phytochemicals Ltd (Sichuan, China). LC-MS grade acetonitrile and methanol were purchased from Merck (Darmstadt, Germany). LC-MS grade formic acid was obtained from Sigma-Aldrich (Mo, USA). Ultrapure water was purified using a Milli-Q 89 water purification system (Millipore, Billerica, MA, USA). The other reagents were all analytical grade.

\section{Animals and drug administration}

Male cynomolgus monkeys ( 7 years old, $7.0 \pm 0.5 \mathrm{~kg}$ weight) were provided by Guangxi cynomolgus medicine applied engineering technology research center (Guangxi province), and were housed an animal room individually in a suspended stainless steel cage at the environment condition set as follow: room temperature and relative humidity was kept with a $12 \mathrm{~h}$ dark/light cycle at $24-26^{\circ} \mathrm{C}$, and $50 \%-70 \%$, respectively. Certified primate pellet diet and clean water were provided every day. Fruits were supplemented regularly for nutrition as is standard practice. All experiments were conducted in accordance with the Regulations of Experimental Animal Administration issued by the State Commission of Science and Technology of the People's Republic of China. Experimental animal protocols were approved by the Animal Ethics Committee of Guangxi University of Chinese Medicine, and all procedures were following the relevant regulations and guidelines.

\section{Preparation of sample solution}

$0.5 \mathrm{~mL}$ of YGMM was diluted with $2 \mathrm{~mL}$ methanol and the dilution was filtered through $0.22 \mu \mathrm{m}$ filter membrane before LC-MS analysis. All samples were stored at $4{ }^{\circ} \mathrm{C}$ until use. Six male cynomolgus monkeys were fasted with only access to water for $12 \mathrm{~h}$ prior to the experiment. $30 \mathrm{~mL}$ of YGMM was orally administered to each monkey. At the time point of $0.5 \mathrm{~h}, 1 \mathrm{~h}, 2 \mathrm{~h}$ and $3 \mathrm{~h}$ after dosing, $1 \mathrm{~mL}$ blood was collected by venipuncture via intragastric gavage respectively and then centrifuged for $10 \mathrm{~min}$ at $3000 \mathrm{rpm} / \mathrm{min}$ at $4^{\circ} \mathrm{C}$ to obtain the supernatant. The supernatant from different time points were mixed together to give the plasma sample and was frozen at $-80{ }^{\circ} \mathrm{C}$ before analysis. After reconstitution, $6 \mathrm{~mL}$ of acetonitrile was added to the plasma and vortex-mixed for $1 \mathrm{~min}$ and then was centrifuged at $12000 \mathrm{rpm} / \mathrm{min}$ at $4^{\circ} \mathrm{C}$ for $10 \mathrm{~min}$. The supernatant was purified by solid-phase extraction and then dried under nitrogen gas at the temperature of $45^{\circ} \mathrm{C}$. The residues were dissolved in $2 \mathrm{~mL}$ of $50 \%$ methanol and then centrifuged at $12000 \mathrm{rpm} / \mathrm{min}$ for $10 \mathrm{~min}$ at $4{ }^{\circ} \mathrm{C}$. Sample solutions were filtered through $0.22 \mu \mathrm{m}$ filter membrane and then $4 \mu \mathrm{L}$ of the solution was injected into the LC-MS system for analysis. A certain amount of 16 reference standards were dissolved in methanol to obtain the standard solutions. Before LC-MS analysis, they were mixed together and then filtered through millipore filters to give the mixed standard solution.

\section{Chromatography and mass spectrometry conditions}

The separation of the components in YGMM and biosamples were conducted on a ACQUITY UPLC BEH C18 column $(2.1 \mathrm{~mm} \times 100 \mathrm{~mm}, 1.7$ $\mu \mathrm{m}$, Waters Corporation, USA) column using the mobile phase consisted of solvent $\mathrm{A}\left(\mathrm{HCOOH}: \mathrm{H}_{2} \mathrm{O}=0.1: 100, v / v\right)$ and solvent $\mathrm{B}\left(\mathrm{CH}_{3} \mathrm{CN}\right)$ on the Shimadzu Nexera Prominence liquid chromatogram system at the gradient eluting procedure optimized as follows: 0-25 min, 5\%-10\%B; 25-40 min, 10\%-16\%B; 40-50 min, 16\%-45\% B, 50-57 min, 45\%-60\% B, and 57-65 min, 100\% B. The flow rate was set at $0.4 \mathrm{~mL} / \mathrm{min}$. The column and autosampler temperature were maintained at $40{ }^{\circ} \mathrm{C}$ and $4{ }^{\circ} \mathrm{C}$, respectively. The inject volume for YGMM and mixed standard solution was $2 \mu \mathrm{L}$ for each, and for the plasma sample was $4 \mu \mathrm{L}$.

Mass spectrometric detection was conducted on the AB SCIEX X500R quadrupole-time of flight (QTOF) coupled with high resolution mass spectrum (HRMS) (Applied Biosystems SCIEX, US) at full scan mode from m/z 100 to 2000 under ESI mode operating in both positive and negative modes. The MS, and MS/MS data of the compounds was acquired in the information-dependent acquirement (IDA) technology mode. The optimized parameters for IDA were set as follows: ion source gas 1 (GS1): 55 psi, ion source gas 2 (GS2): 55 psi, curtain gas: 35 psi, temperature: $600^{\circ} \mathrm{C}$, and CAD gas: 7 . For TOF MS: mass range of the components, $m / z 100-2000$, declustering potential (DP): $\pm 80 \mathrm{~V}$, collision energy (CE): $\pm 35 \mathrm{~V}$, and CE spread: 0 V. For TOF MSMS: mass range of the fragments, $m / z 100-2000$, declustering potential (DP): 80 $\mathrm{V}$, collision energy (CE): $\pm 35 \mathrm{~V}$, and CE spread: $15 \mathrm{~V}$, and accumulation time: $0.05 \mathrm{~s}$. Data acquisition and analysis were controlled by SCIEX OS software (Ver. 1.3.1, AB SCIEX Co.). 
The systematic information on chemical constituents isolated or identified from the 12 individual herbs in YGMM was collected and sorted out by retrieving the published literatures involving chemical constituents studies, fingerprint of medicinal materials studies, reviews, and master's and doctoral dissertations, etc. As a result, a self built components database included compound name, and chemical formulas of each compound was established for further structural elucidation. All the compounds collected in the self built database were listed in Table S1 (Supplementary information).

\section{The comprehensive research strategy and data processing}

In order to rapidly characterize the chemical profile of YGMM, an investigate research strategy that integrated the UPLC-Q-TOF-MS method and self built components database was established. As shown in Fig.1, firstly the chemical components of all the individual medical herbs were collected in a excel table to give the self built components database, which contained the compound name and chemical formula for each compound. Secondly, the raw MS data of YGMM was acquired using the established UPLC-Q-TOF-MS method. After that the excel table was imported into the SCIEX OS software, and data filtering and screening were automatically performed. Adducts including $+\mathrm{H},+\mathrm{Na}$, and $+\mathrm{K}$ were selected for positive mode, and for negative mode, adducts including $+\mathrm{Cl},+\mathrm{HCOO}$ and $-\mathrm{H}$ were selected. The extracted ion chromatograms (XIC) Width was set as $0.02 \mathrm{Da}$. The confidence levels of compounds for the qualitative rules were set as follow: mass accuracy tolerance set at $\pm 10 \mathrm{ppm}$, and combined score weight for it was $60 \%$; different isotope ratio tolerance set at \pm 10 ppm, and combined score weight for it was $40 \%$. The third step of the data analysis strategy was to screen out the candidate compounds of YGMM and confirm the source of each component by using the above-mentioned screening rules. By analyzing the MS/MS fragmentation patterns, and also by comparison with standard compounds and those data reported in the literatures, the chemical components in YGMM were finally confirmed from the screened candidate compounds. Serum pharmacochemistry analysis of the prototypes in cynomolgus monkey plasma after oral administration was carried out by using the same UPLC-Q-TOF-MS method in IDA mode. XIC mode was applied to extract the prototypes by comparison the retention time, MS, and MS/MS fragments data with those identified components in YGMM.

\section{Results}

(Insert here) Table 1 Identification of chemical constituents of YGMM and prototypes in plasma (See the end of the text)

By searching the published literatures of 12 single herb medicines, a total of 667 components were collected in the self built components database (Table S1, Supplementary information). The solution of YGMM was analyzed in both in positive and negative ion modes by using UPLC-Q-TOF-MS in the IDA mode. The base peak chromatograms (BPC) in positive and negative modes of YGMM are showed in Fig. 2. Using the established data analysis strategy, 415 compounds were initially screened out as candidate compounds in YGMM, as shown in Table S2 (Supplementary information). A total of 117 compounds and 61 prototypes were unambiguously identified or tentatively characterized in YGMM and plasma of cynomolgus monkey, respectively, as shown in Table 1, which included the information of retention time, molecular formula, mass weight, mass error, and main fragment of each compound. The chemical structures of the main compounds in YGMM were shown in Fig.3, and all the compounds identified were shown in Fig.S1 (Supplementary information).

\section{Identification of phenolic compounds in YGMM}

Phenolic compounds are well known bioactive secondary metabolites in medicinal plants, which have been proved to possess antioxidative, antimicrobial, and anticarcinogenic activities. In their structures, usually there are more than one phenolic hydroxyl group attached to one or more benzene rings. Besides hydroxyl group, other common substituents in their structures are methoxy, carboxylic acid, glucose, rhamnose and xylose moieties. In the negative ion mode, neutral losses of $18 \mathrm{Da}\left(\mathrm{H}_{2} \mathrm{O}\right), 28 \mathrm{Da}(\mathrm{CO})$, and $44 \mathrm{Da}\left(\mathrm{CO}_{2}\right)$ were often detected in the $\mathrm{MS} / \mathrm{MS}$ spectra[48]. In our study, 17 phenolic acids were detected in YGMM. Compound 2 gave the [M+H] $]^{+}$ion at $m / z 171.0290$, which corresponded to the molecular formula of $\mathrm{C}_{8} \mathrm{H}_{8} \mathrm{O}_{4}$. In its MS/MS spectra, the fragment ions of $m / z 153.0196\left[\mathrm{M}+\mathrm{H}-\mathrm{H}_{2} \mathrm{O}\right]^{+}, 135.0087\left[\mathrm{M}+\mathrm{H}-2 \mathrm{H}_{2} \mathrm{O}\right]^{+}$, and $109.0260\left[\mathrm{M}+\mathrm{H}-\mathrm{CO}_{2}\right]^{+}$were observed, which indicated the hydroxyl and carboxyl groups in the chemical structure, and thus compound 2 were identified as gallic acid. Compound 11 produced precursor ions at $\mathrm{m} / \mathrm{z} 367.1036\left([\mathrm{M}-\mathrm{H}]^{-}\right)$in the negative ion mode, and its molecular formula was supposed as $\mathrm{C}_{17} \mathrm{H}_{20} \mathrm{O}_{9}$. Fragments of this compound were found at $m / z 193.0503,191.0566,173.0488,149.0612$, and 134.0373 in the high-collision-energy scan, which mainly resulted from the successively losses of one ferulic acid, one quinic acid, one $\mathrm{H}_{2} \mathrm{O}$ and one $\mathrm{CO}_{2}$. The detail fragment pathways of compound 11 were proposed in Fig.S2 (Supplementary information) and was unambiguously identified as 3-O-feruloylquinic acid after confirmed with reference standard and those data reported in literature[49]. Based on the high resolution MS data and characteristic fragmentation patterns, other phenolic acids were identified respectively (Table 1). 


\section{Identification of flavonoids in YGMM}

In total of 25 flavonoids were identified in YGMM, which could be classified as flavones, flavonols, flavanones, and flavanols. RDA cleavages at $\mathrm{B}^{1,3-}$ position was the major fragmentation pathway observed in their MS/MS spectra. Other neutral losses such as $\mathrm{CH}_{3}(15 \mathrm{Da}), \mathrm{CH}_{2} \mathrm{O}(30$ $\mathrm{Da}), \mathrm{H}_{2} \mathrm{O}(18 \mathrm{Da}), \mathrm{CO}(28 \mathrm{Da}), \mathrm{CO}_{2}(44 \mathrm{Da})$, glucose (162 Da), rhamnose (146 Da), and xylose (132 Da) were also usually detected. The major fragmentation pathway of a representative compound was proposed and shown in Fig. S3 (Supplementary information).

Compound 32 showed a protonated ion at $\mathrm{m} / \mathrm{z} 449.1085$, indicating the chemical formula of $\mathrm{C}_{21} \mathrm{H}_{22} \mathrm{O}_{11}$. Using the high-collision-energy scan mode, fragment ions at $\mathrm{m} / \mathrm{z} 287.0550,151.0032$, and 135.0449 were observed. lon at $\mathrm{m} / \mathrm{z} 287.0550$ was generated by the loss of one glucose (162 Da) group. Daughter ions at $m / z 151.0032$, and 135.0449 were the characterical fragments of flavones after RDA cleavage at $\mathrm{B}^{1,3-}$ position[4]. Thus, compound $\mathbf{3 2}$ were tentatively identified as isookanin-7-0- $\beta$-diglucopyranoside. The similar fragmentation behaviors could also been observed in the MS/MS spectra of compound 57. Beside the characterical ion generated by the RDA cleavage at position $\mathrm{B}^{1,3-}$, other neutral loss such as $\mathrm{H}_{2} \mathrm{O}(18 \mathrm{Da})$ and $\mathrm{CO}_{2}(44 \mathrm{Da})$ were also used for identification, which resulted in the deduction of compound 57 as hesperetin, and it was firmly identified by comparison with the reference compound. Based on the similar fragmentation pathways, other flavonoids and their glycosides were identified, respectively.

Though sharing the same basic aglycone as the other flavonoids, the number and position of substituents such as hydroxyl and methyl groups on different rings (A, B, and C) of polymethoxylated flavones detected in YGMM resulted in their different molecular formulas and high resolution mass values. Compound 102 were taken as an example to characterize the typical MS/MS fragmentation behaviors of these polymethoxylated compounds. As shown in Fig.S4 (Supplementary information). Compound $\mathbf{1 0 2}$ gave the $[\mathrm{M}+\mathrm{Na}]^{+}$ion at $\mathrm{m} / \mathrm{z}$ and its molecular formula was established as $\mathrm{C}_{21} \mathrm{H}_{24} \mathrm{O}_{8}$. The consequently losses of methyl groups produced the fragment ions at $\mathrm{m} / \mathrm{z}$ $412.1150\left[\mathrm{M}+\mathrm{Na}-\mathrm{CH}_{3}\right]^{+}$, and $397.0894\left[\mathrm{M}+\mathrm{Na}-2 \mathrm{CH}_{3}\right]^{+}$, respectively. Fragment ion at $381.0973\left[\mathrm{M}+\mathrm{Na}-\mathrm{CO}-\mathrm{H}_{2} \mathrm{O}\right]^{+}$was corresponded with the losses of one $\mathrm{CO}$ and one $\mathrm{H}_{2} \mathrm{O}$ molecules. Beside the fragment ions mentioned above, fragment ion at 263.0543 corresponded to [M+Na$\left.\mathrm{C}_{10} \mathrm{H}_{12} \mathrm{O}_{2}\right]^{+}$, which was generated by the characteristic RDA cleavage at $\mathrm{B}^{1,3-}$ position. Fragment ions at $248.0283\left[\mathrm{M}+\mathrm{Na}-\mathrm{C}_{10} \mathrm{H}_{12} \mathrm{O}_{2}-\mathrm{CH}_{3}\right]^{+}$and 233.0046[M+Na- $\left.\mathrm{C}_{10} \mathrm{H}_{12} \mathrm{O}_{2}-2 \mathrm{CH}_{3}\right]^{+}$were also observed after expelling one and two methyl groups, respectively. Thus, compound 102 were tentatively identified as $5,6,7,8,3^{\prime}, 4^{\prime}$-hexamethoxyflavanone[50].

\section{Identification of phthalide compounds in YGMM}

Phthalide compounds were bioactive components of LC and AS corresponding for their pharmacological properties, such as blood vessel protection, anti-thrombotic, anti-hypertensive, anti-atherosclerosis, anti-inflammatory, and anti-asthma effects. Neutral losses such as $\mathrm{CH}_{3}(15$ Da), $\mathrm{C}_{4} \mathrm{H}_{8}\left(56 \mathrm{Da}\right.$, side chain), $\mathrm{H}_{2} \mathrm{O}(18 \mathrm{Da}), \mathrm{CO}(28 \mathrm{Da})$, and $\mathrm{CO}_{2}(44 \mathrm{Da})$ were also usually detected. The major fragmentation pathways were proposed and shown in Fig. S5 (Supplementary information). Based on these similar fragmentation patterns and reference standards, other phthalide compounds were identified respectively.

\section{Identification of monoterpenes in YGMM}

In total of 5 monoterpenes from RG and RP were identified in YGMM. Neutral losses including $\mathrm{H}_{2} \mathrm{O}(18 \mathrm{Da}), \mathrm{CH}_{2} \mathrm{O}(30 \mathrm{Da}), \mathrm{CO}(28 \mathrm{Da})$, glycose $(162 \mathrm{Da})$, and p-hydroxybenzoic acid (138 Da) of these compounds in the MS/MS spectra were helpful to the confirm the existence of substituents such as hydroxyl, carbonyl, p-hydroxybenzoic acid, and glycosyl groups in the molecules. For example, in the MS/MS spectra of compound 18 (Fig. S6, Supplementary information), fragment ions at $\mathrm{m} / \mathrm{z} 327.1070$ (fragment ion), and 121.0295 (group ion) were detected, which corresponding to $\left[\mathrm{M}-\mathrm{H}-\mathrm{C}_{7} \mathrm{H}_{5} \mathrm{O}_{2} \text { (benzoic acid)- } \mathrm{CH}_{2} \mathrm{O}\right]^{-}$, and $\left[\mathrm{C}_{7} \mathrm{H}_{5} \mathrm{O}_{2}\right]^{-}$, respectively. Thus, compound $\mathbf{1 8}$ were assigned as peoniflorin, and also was confirmed by comparison with the MS and MS/MS data with reference standard. Using the same method, compound 12, 20, 69, and 90 were tentatively characterized as rehmapicroside, lactiflorin, mudanpioside $D$, and (Z)-(1S,5R)- $\beta$-pinen-10-yl- $\beta$ vicianoside, respectively.

\section{Identification of triterpenoid saponins in YGMM}

Triterpenoid saponins were mainly classified into tetracyclic and pentacyclic types due to the ring numbers in their structures. In negative ion mode, triterpenoid saponins usually showed intense deprotonated ion, due to the existence of one or more hydroxyl groups in the structure, and were apt to expel the glucose (162 Da), rhamnose (146 Da) and xylose (132 Da) moieties[51]. The species and amount of glycosyl 
groups could be deduced from the fragment mass different. Major fragmentation pathways proposed for a typical triterpenoid saponin (compound 80) were showed in Fig.S7 (Supplementary information). Compound $\mathbf{8 0}$ showed a quasi-molecular ion [M+H] ${ }^{+}$at 917.4744 , and its molecule formula was established as $\mathrm{C}_{45} \mathrm{H}_{72} \mathrm{O}_{19}$. In its $\mathrm{MS} / \mathrm{MS}$ spectra, characterical ions at $\mathrm{m} / \mathrm{z} 899.4642$ and 881.4608 were generated by successive losses of one $\mathrm{H}_{2} \mathrm{O}(18 \mathrm{Da})$ and two $\mathrm{H}_{2} \mathrm{O}(36 \mathrm{Da})$ molecules, respectively. The other characterical ions at $\mathrm{m} / \mathrm{z} 737.4113$, 593.3722 , and 429.3003 represented the successive losses of one, two, and three glucose (162 Da) units, respectively. Thus, compound 80 was tentatively characterized as polygoside A. Fragmentation patterns of the other triterpenoid saponins could be observed at their sugar or carbon side chains and thus identified.

\section{Identification of other compounds in YGMM}

Using the same data analysis strategy, other compounds (See Table 1) were identified by detail analysis of their MS, and MS/MS data, and comparison of their fragmentation behaviors with those previously reported in the literature. For example, the Fragmentation patterns of the representative anthraquinone (emodin-3-methyl ether, compound 110) were displayed in Fig.S8 in Supplementary information.

\section{Identification of prototypes in cynomolgus monkey plasma}

Serum pharmacochemistry analysis was conducted to study the absorbed constituents in vivo, using cynomolgus monkey as animal mode. The chemical profiles study of YGMM were helpful for the fast investigation of the absorbed prototypes in vivo. The blank and drugged blood samples were analyzed in both negative and positive modes by the established UPLC-Q-TOF-MS method (Fig. 4). The extracted ion chromatograms (XIC) of the absorbed prototypes of YGMM were shown in Fig.5 and Table 1, respectively, and these compounds were confirmed by comparing their accurate mass measurements and retention times with the identified components in YGMM. As a result, a total of 61 prototypes were screened out.

\section{Discussion}

Although the chemical composition of each single herbal medicine contained in YGMM have been studied and reported, the chemical profiles of YGMM have not been systematically characterized. To comprehensive characterize the constituents of such complex system is challenging, due to the various type structures such as flavonoids, phenolic acids, monoterpenes, and anthraquinones, etc. The established data analysis strategy in this study might be helpful to the fast characterization of chemical profiles in YGMM, and the self built database have been proved greatly helpful in the chemical identification because it could greatly reduces the scope of analysis and improves the accuracy of compound identification[4, 49]. As shown in Fig.1, based on the reported chemical components from the 12 the single herbal medicines, self built database could exclude many isomers from the other herbal medicines, and the candidate compounds were fast screened out by matching the experimental MS values with those theoretical value, and finally, the identified compounds were confirmed by comparisons of retention times, and MS/MS fragment patterns with standard compounds or those data reported.

Although TCM contains complex chemical components, only the ones that can be absorbed into the blood may produce effects[8]. Serum pharmacochemistry analysis is an effective tool to study absorbed compounds in blood, which may unveil the potential biomarkers in YGMM. Cynomolgus monkeys are a useful preclinical model[52] and have been applied in the pharmacokinetic study by our group[8]. The absorbed prototypes of YGMM in cynomolgus monkey plasma were studied by using the established data analysis strategy and the results might be used for its quality control research. The work of identifying metabolites from YGMM in vivo was still in progress by our lab.

\section{Conclusions}

In this study, a rapid and effective data analysis strategy based on UPLC-Q-TOF-MS and self built components database was applied to the fast identification of the chemical constituents of YGMM in vitro and prototypes in vivo. 667 compounds were collected from the literatures of the 12 single herb medicines. With the help of the SCIEX OS software, 415 compounds were initially screened as candidate compounds in YGMM. Among which, a total of 117 compounds were identified or tentatively characterized, by detail analysis of their accurate mass measurements, characteristic neutral loss, MS/MS fragment pathways, and also by comparisons with standards and those data reported in the literatures, and these compounds were tentatively distributed to 12 medicinal materials, which included 17 phenolic acids, 25 flavonoids, 4 alkaloids, 10 phthalides, 5 monoterpenes, 8 triterpenoid saponins, 9 anthraquinones, and 39 other compounds. Serum pharmacochemistry analysis of the plasma of cynomolgus monkey resulted in the identification of 61 prototypes, which included 13 phenolic acids, 21 flavonoids, 8 phthalides, 3 monoterpenes, 4 triterpenoid saponins, and 12 other compounds. To the best of our knowledge, it was the first 
comprehensive study of the chemical profile of YGMM and its prototypes in vivo. Our study might provide a scientific basis for further research on pharmacological effects, action mechanism and quality control of YGMM.

\section{Declarations}

\section{Acknowledgements}

Not applicable.

\section{Authors' contributions}

WW carried out the experiments, drafted the manuscript and analyzed the compounds; LSW graphed the picture, YXS and DJG contributed to the design and interpretation of the research. All authors read and approved the final manuscript.

\section{Funding}

This work is supported by the Initial Scientific Research Fund of Introduced Doctors in 2017 of Guangxi University of Chinese Medicine (2017BS044); Guangxi Science and Technology Plan Project (AB17195019, AD17129010, 17-259-20, and AD17195024); The Special Fund for Bagui Scholars of Guangxi; Innovation Project of Guangxi Graduate EducationYCSW2019170)

\section{Availability of data and materials}

The research data generated from this study is included within the article and Supplementary information.

\section{Ethics approval and consent to participate}

Experimental animal protocols were approved by the Animal Ethics Committee of Guangxi University of Chinese Medicine, and all procedures were following the relevant regulations and guidelines.

\section{Consent for publication}

Not applicable.

\section{Competing interests}

The authors declare that they have no competing interests.

\section{Author details}

1. College of Pharmacy and International Cooperative Laboratory of Traditional Chinese Medicine Modernization and Innovative Drug Development of Chinese Ministry of Education, Jinan University, Guangzhou 510632, China. 2. Guangxi Key Laboratory of Efficacy Study on Chinese Materia Medica, Guangxi University of Chinese Medicine, Nanning, Guangxi 530200, China. 3. National and Region joint Engineering Center for Anticancer Drug Development, Guangxi Hebabiz Pharmaceutical Co. Ltd., Qinzhou 535000, China. 4. Faculty of Pharmacy, Guangxi University of Chinese Medicine, Nanning 530200, China

\section{Abbreviations}

YGMM $₫$ Yigan mingmu oral liquid, TCM: Traditional Chinese medicine, ESI-MS: Electrospray ionization-mass spectrometer, LC-MS: Liquid chromatography paired with mass spectrometry, UPLC-Q-TOF-MS: Ultra performance liquid chromatography quadrupole time of flight mass spectrometer BPC: base peak chromatograms, RDA: Retro Diels Alder, XIC: extracted ion chromatograms. 


\section{References}

1. Zuo AH, Wang L, Xiao HB, Li LM, Liu YH, Yi JH. Identification of the absorbed components and metabolites in rat plasma after oral administration of Rhizoma Chuanxiong decoction by HPLC-ESI-MS/MS. J Pharm Biomed Anal. 2011; 56(5): 1046-56.

2. Xian Z, Wang SS, Dennis C, Hosen K, Valentina RN, Kelvin C, et al. Synergistic effects of chinese herbal medicine: a comprehensive review of methodology and current research. Front Pharmacol. 2016; 7: 201.

3. Liu T, Tian XM, Li ZQ, Han F, Ji B, Zhao YL, et al. Metabolic profiling of Gegenqinlian decoction in rat plasma, urine, bile and feces after oral administration by ultra high performance liquid chromatography coupled with Fourier transform ion cyclotron resonance mass spectrometry. J Chromatogr B. 2018; 1079: 69.

4. Dou XX, Lin S, Tian XH, Zhang YH, Guo X, Ye J, et al. Systematic characterization of the chemical constituents in vitro and prototypes in vivo of Dingkun Dan by UPLC-Q-TOF/MSE ${ }^{\mathrm{E}}$ combined with the UNIFI ${ }^{\mathrm{TM}}$ software. Biomed Chromatogr. 2020; 34(10): 1-10.

5. Wang CJ, Jiang YQ, Liu DH, Yan HX, Ma SC. Characterization of phloroglucinol derivatives and diterpenes in Euphorbia ebracteolata Hayata by utilizing ultra-performance liquid chromatography/quadrupole time-of-flight mass spectrometry. J. Pharm. Anal. 2013; 3: 2927.

6. Chen YX, Mo QG, Xie BB, Ma BX, Zang XY, Zhou G, et al. Hepatoprotective activity of Yigan Mingmu oral liquid against isoniazid/rifampicin-induced liver injuries in rats. Chin Med. 2018; 9: 165-78.

7. Su SL, Cui WX, Zhou W, Duan JA, Shang EX, Tang YP. Chemical fingerprinting and quantitative constituent analysis of Siwu decoction categorized formulae by UPLC-QTOF/MS/MS and HPLC-DAD. Chin Med. 2013; 8(1): 5.

8. Hao EW, Qin JF, Wei W, Miao JH, Xie Y, Pan XL, et al. Identification and analysis of components in Yizhi Granule and cynomolgus monkey plasma after oral administration by UPLC/ESI-Q-TOF MS and their protective Effects on PC12 Cells. J. Anal. Methods Chem. 2020; 2020: https://doi.org/10.1155/2020/5165631.

9. He J, Gao XX, Tian JS, Qin XM, Du GH, Zhou YZ. Analysis on chemical constituents in Bupleuri 『adix and Paeoniae \adix Alba by UPLCMS and their contribution to Xiaoyao powder. J Shanxi Med Univ. 2018; 49(4): 375-82.

10. Ren J, Liu X, Li WD, Cai H, Zhu XC, Cai BC. Qualitative analysis of major constituents of raw and processed Paeonia Lactiflora by UHPLCQ-TOF-MS/MS. Chin J Chin Mater Med. 2015; 40(9): 1762-70.

11. Liu J, Chen L, Fan CR, Li H, Huang MQ, Xiang Q, et al. Qualitative and quantitative analysis of major constituents of Paeoniae Radix Alba and Paeoniae \adix \ubra by HPLC- DAD-Q-TOF-MS/MS. Chin J Chin Mater Med. 2015; 40(9): $1762-70$.

12. Zhang TT, Ju Z, Ji Y, Zhu D, Wang AL, Zhang WJ, et al. Research progress on chemical constituents and analytical methods of Radix Paeoniae Alba. Guangzhou Chem Ind. 2020; 48(18): 20-30.

13. Tan SY, Xiao X, Piao SH, Li SS. Analysis and identification of water-soluble components of Paeonia lactiflora. J Chin Med Materials. 2017; 40(1): 94-100.

14. Guo MN, Liu SX, Zhao YM, Zhang Tie Jun, Lin LD. Analysis on chemical constituents in Bupleuri oadix by HPLC-Q-TOF-MS. Chin Trad Herb Drugs. 2016; 47(12): 2044-52.

15. Ye YH, Shi Y, Zhang BW, Chhen WB, Ma YN, Yu H. Fingerprint analysis of Bupleurum chinense roots from different origins by UPLC/QTOF-MS. Chin J Exp Tradit Med Form. 2019; 25(18): 124-9.

16. Yang Fude DX, Yin Xingbin, Wang Wenping.You Longtai, Ni Jian. Radix Bupleuri: A review of traditional uses, botany, phytochemistry, pharmacology, and toxicology. Biomed Res Int. 2017; 2017: 1-22.

17. Yin QC, Chen CC, Tian JS, Gao XX, Qin XM, Du GH, et al. Analysis of serum pharmacochemistry from Radix Bupleuri-Radix Paeoniae Alba herb using UPLC-QE-Orbitrap-MS technology. Acta Pharm. Sin. B. 2019; 54(12): 2296-2302.

18. Xing TT, Zhao Xi Juan, Zhang Yi Dan, Fang LY. Fast separation and sensitive quantitation of polymethoxylated flavonoids in the peels of citrus Using UPLC-Q-TOF-MS. J Agric Food Chem. 2017; 65(12): 2615-27.

19. Zhang JY, Zhang Q, Zhang HX, Ma J, Lu JQ, Qiao YJ. Characterization of polymethoxylated flavonoids (PMFs) in the peels of 'Shatangju' Mandarin (Citrus reticulata Blanco) by online high-performance liquid chromatography coupled to photodiode array detection and electrospray tandem mass spectrometry. J Agric Food Chem. 2012; 60(36): 9023-34.

20. Zhao X, Xing Tiantian, Li Yuanfang, Jiao Bining, Jiang Dong. Efficient analysis of phytochemical constituents in the peel of Chinese wild citrus Mangshanju (Citrus reticulata Blanco) by ultra high performance liquid chromatography-quadrupole time-of-flight-mass spectrometry. J Sep Sci. 2018; 41(9): 1947-59.

21. Han W. Advances in chemical constituents and pharmacological effects of Ligusticum chuanxiong. Mod Chin Med. $2017 ; 19(9)$ : 1341-9.

22. Zhang JH, Wu WD, Liu JT, Xu J, Huang FQ, Liu L, et al. Rapid analysis of chemical constituents of Huoxue Zhitong capsules based on UPLC-Q-TOF/MS Chin Trad Herb Drugs. 2020; 51(12): 3139-46.

Page $8 / 22$ 
23. Xu WYJ, Lian HY, Liang QD, Ma ZC, Wang YG, Tang XL, et al. Chemical comparison between decoctions of Angelicae sinensis radix and Chuanxiong rhizoma by UPLC-QTOF-MS. Pharm J Chin PLA. 2015; 31(1): 4-9.

24. Yan WH, Cao HH, Guo S, Gu L, Hu W, Cheng M, et al. UPLC fingerprint and multi- components content determination of different processed products of Angelica sinensis. Chin J Chin Mater Med. 2019; 44(12): 2449-2510.

25. Jin Y, Wei YQ, Ding JB, Li YL, Ma JL. Research and application of Lycii Fructus in medicinal field. Chin Herb Med 2018; 10 (4): $339-52$.

26. Pan FL, Han X, Ji YH, Jiang XQ, Sen ML, Liu Y, et al. Selection of quality control components from Fructus lycii based on multicomponent metabolism. World Chin Med. 2020; 15(13): 1865-71.

27. Lv W, Zhao Q, Huang S, Liu D, Wang ZY, Yang J, et al. Discovery and validation of biomarkers for Zhongning goji berries using liquid chromatography mass spectrometry. J Chromatogr B. 2020; 1142: 122037.

28. Han YQ, Zhou MG, Wang LQ, Ying XH, Peng JM, Jiang M, et al. Comparative evaluation of different cultivars of Flos Chrysanthemi by an anti-inflammatory-based NF-KB reporter gene assay coupled to UPLC-Q/TOF MS with PCA and ANN. J Ethnopharmacol. 2015; 174: 38795.

29. Li YF, Hao YM, Gao BY, Geng P, Huang HQ, Yu L, et al. Chemical profile and in vitro gut microbiota modulatory, anti-inflammatory and free radical scavenging properties of chrysanthemum morifolium cv. Fubaiju. J. Funct. Foods. 2019; 58: 114-22.

30. Du. Jing Sheng, Wu LQ, Liu JG, Ma HY. Rapid analysis of chemical constituents of Chrysanthemum morifolium based on uplc-q-tof-ms. J Chin Med Materials. 2017; 40(3): 621-3.

31. Zhang LX, Fan Y, Wei Y, Li FF, Li X. Determination of twelve components in Chrysanthemum indicum by quantitative analysis of multicomponents by single marker. Chin J Pharm Anal 2020; 40(2): 218-26.

32. An Y, Yang JH, Wang CC, Cai HL. Analysis of chemical constitutents in Cassiae Semen by UHPLC/Q-TOF-MS. Chin Trad Pat Med. 2017; 39(4): 776-81.

33. Wang Q, Zhang WD, Song XM, Wang Y, Wang R, Wang PY, et al. Simultaneous determination of twelve Anthraquinones in Cassiae Semen from different areas by HPLC. Pharm J Chin PLA. 2012; 28(6): 502-5.

34. Luo Y, Zhang L, Wang WH, Liu B. Components identification in Cassiae Semen by HPLC-IT-TOF MS. Chin J Pharm Anal 2015; 35(8): 1408-16.

35. Shang ZP, Wang F, Wang ZJ, Zhao WQ, Mei XD, Lu JQ, et al. Rapid identification of homoisoflavonid sulfated derivatives in sulfated fumigated Ophiopogon japonicus by UHPLC-LTQ-orbitrap mass spectrometry. J. Chin. Mass Spectr. Soc. 2018; 39(2): $180-91$.

36. Wu FM, Cai XY, Wang P, Bao X, Li M, Zhou J. HPLC simultaneous determination of contents of 5 saponin constituents in Ophiopogonis Radix. Chin J Chin Mater Med. 2015; 40(20): 4022-5.

37. Yan RY, Ma FX, Yu HS, Kang LP, Zhang J, Zhao Y, et al. Identification of steroidal saponins in Ophiopogonis radix by UPLC-Q-TOF-MSE combined with relative retention time. Chin J Exp Tradit Med Form. 2016; 22(24): 43-50.

38. Zhang YB, Jiang Zhen Zuo, Wang YF, Yang L, Yang F, Yu HJ. Analysis of chemical constituents in fresh,dried and prepared Rehmanniae Radix by UPLC/ESI-Q-TOF MS. Chin Trad Pat Med. 2016; 38(5): 1104-8.

39. Guo HJ, Zhao HX, Kanno YC, Li W, Mu YL, Kuang XZ, et al. A dihydrochalcone and several homoisoflavonoids from Polygonatum odoratum are activators of adenosine monophosphate-activated protein kinase. Bioorg Med Chem Lett. 2013; 23(11): 3137-9.

40. Zhang YB, Jiang ZZ, Wang YF, Yang L, Yang F, Yu HJ. Analysis of chemical constituents in fresh,dried and prepared Rehmanniae Radix by UPLC/ESI-Q-TOF MS. Chin Trad Pat Med. 2016; 38(5): 1104-8.

41. Tao Y, Jiang YH, Tang KJ, Li WD, Cai BC. Comparison of chemical constituents of crude and processed products of Rehmannia glutinosa by using UHPLC-Q-TOF/MS. J Chin Med Materials. 2020; 43(7): 1642-8.

42. Tao Y, Jiang YH, Tang KJ, Li WD, Cai BC. Comparison of Chemical Constituents of Crude and Processed Products of Rehmannia glutinosa by Using UHPLC-Q-TOF/MS. Tradit Chin Drug Res Pharmacol. 2016; 27(1): 102-6.

43. Liu W, Yin DX, Zhang T, Qiao Q, Yang YQ, Wang WL. Phytochemical profiles and antioxidant activity of Rehmannia glutinosa from different production locations. Chem Biodivers. 2020; 10.1002/cbdv.202000341.

44. Liu QB, Li W, Nagata K, Fu Hong Wei, Okada S, Tanabe I, et al. Isolation, structural elucidation, and LC-MS analysis of steroidal glycosides from Polygonatum odoratum. J Agric Food Chem. 2017; 66(2): 1-26.

45. Hu X, Zhao HD, Shi SY, Li H, Zhou XL, Jiao FP, et al. Sensitive characterization of polyphenolic antioxidants in Polygonatum odoratum by selective solid phase extraction and high performance liquid chromatography-diode array detector-quadrupole time-of-flight tandem mass spectrometry. J Pharm Biomed Anal. 2015; 112: 15-22.

46. Pang X, Zhao JY, Wang YJ, Wei Z, Zhang J, Chen XJ, et al. Steroidal glycosides, homoisoflavanones and cinnamic acid derivatives from Polygonatum odoratum and their inhibitory effects against influenza A virus. Fitoterapia. 2020; 146: 104689. 
47. Zhang H, Chen L, Kou JP, Zhu DN, Qi J, Yu BY. Steroidal sapogenins and glycosides from the fibrous roots of Polygonatum odoratum with inhibitory effect on tissue factor (TF) procoagulant activity. Steroids. 2014; 89: 1-10.

48. Yang ST, Wu X, Rui W, Guo J, Feng YF. UPLC/Q-TOF-MS analysis for identification of hydrophilic phenolics and lipophilic diterpenoids from Radix Salviae Miltiorrhizae. Acta Chromatogr. 2015; 1(4): 1-18.

49. Tang XY, Zeng JX, Dai ZQ, Chen MH, Ye MN, Yao ZH, et al. Identification and characterization of chemical constituents in Qi-Lin pills and their metabolites in rat bio-samples after oral administration using ultra-high performance liquid chromatography with quadrupole timeof-flight mass spectrometry. J Pharm Biomed Anal. 2020; 188: 113402.

50. Zheng YY, Zeng X, Peng W, Wu Z, Su WW. Characterisation and classification of Citri Reticulatae Pericarpium varieties based on UHPLCQ-TOF-MS/MS combined with multivariate statistical analyses. Phytochem Anal. . 2019; 30(3): $278-91$.

51. Xu L, Liu Y, Wu HF, Wu H, Zhou A. Rapid identification of chemical profile in Gandou decoction by UPLC-Q-TOF-MS E coupled with novel informatics UNIFI platform. J Pharm Biomed Anal. 2020; 10(1): 1-15.

52. Buse E. Development of the immune system in the cynomolgus monkey: The appropriate model in human targeted toxicology? J Immunotoxicol. 2005; 2(4): 211-6.

\section{Table}

Table 1 Identification of chemical constituents of YGMM and prototypes in plasma 


\begin{tabular}{|c|c|c|c|c|c|c|c|c|c|c|}
\hline No. & $\begin{array}{l}\text { Retention } \\
\text { Time }\end{array}$ & $\begin{array}{l}\text { Adduct / } \\
\text { Charge }\end{array}$ & $\begin{array}{l}\text { Precursor } \\
\text { Mass }\end{array}$ & $\begin{array}{l}\text { Found At } \\
\text { Mass }\end{array}$ & $\begin{array}{l}\text { Mass } \\
\text { Error } \\
(\mathrm{ppm})\end{array}$ & Formula & Compound name & $\begin{array}{l}\text { MS/MS fragment ions } \\
(\mathrm{m} / \mathrm{z})\end{array}$ & Source & Prototypes \\
\hline 1 & 0.98 & {$[\mathrm{M}-\mathrm{H}]^{-}$} & 117.0193 & 117.0193 & -0.3 & $\mathrm{C}_{4} \mathrm{H}_{6} \mathrm{O}_{4}$ & Succinic Acid & $117.0910[\mathrm{M}-\mathrm{H}]^{-}$ & AA & \\
\hline $2 *$ & 1.06 & {$[\mathrm{M}+\mathrm{H}]^{+}$} & 171.0290 & 171.029 & 1.3 & $\mathrm{C}_{7} \mathrm{H}_{6} \mathrm{O}_{5}$ & Gallic acid & $\begin{array}{c}153.0196[\mathrm{M}+\mathrm{H}- \\
\left.\mathrm{H}_{2} \mathrm{O}\right]^{+} \\
135.0087[\mathrm{M}+\mathrm{H}- \\
\left.2 \mathrm{H}_{2} \mathrm{O}\right]^{+}, \\
109.026\left[\mathrm{M}+\mathrm{H}^{-} \mathrm{CO}_{2}\right]^{+}\end{array}$ & $\begin{array}{c}\mathrm{BC} \\
\mathrm{RP}, \mathrm{LC}\end{array}$ & $\mathrm{P}$ \\
\hline $3 *$ & 1.85 & {$[\mathrm{M}-\mathrm{H}]^{-}$} & 167.0350 & 167.0351 & 0.6 & $\mathrm{C}_{8} \mathrm{H}_{8} \mathrm{O}_{4}$ & Vanillic acid & $\begin{array}{c}167.0360[\mathrm{M}-\mathrm{H}]-, \\
123.0445\left[\mathrm{M}-\mathrm{H}-\mathrm{CO}_{2}\right]-\end{array}$ & AS, LC & $\mathrm{P}$ \\
\hline 4 & 1.99 & {$[\mathrm{M}-\mathrm{H}]^{-}$} & 153.0193 & 153.0195 & 0.8 & $\mathrm{C}_{7} \mathrm{H}_{6} \mathrm{O}_{4}$ & Protocatechuic acid & $109.0293\left[\mathrm{M}-\mathrm{H}-\mathrm{CO}_{2}\right]-$ & RG & \\
\hline 5 & 2.01 & {$[\mathrm{M}+\mathrm{HCOO}]^{-}$} & 373.1140 & 373.1141 & 0.3 & $\mathrm{C}_{15} \mathrm{H}_{20} \mathrm{O}_{8}$ & Paeonoside & $\begin{array}{c}373.1300[\mathrm{M}+\mathrm{HCOO}]- \\
329.0862[\mathrm{M}+\mathrm{HCOO}- \\
\left.\mathrm{CO}_{2}\right]-\end{array}$ & $\mathrm{RP}$ & $\mathrm{P}$ \\
\hline 6 & 3.06 & {$[\mathrm{M}-\mathrm{H}]^{-}$} & 461.1664 & 461.1663 & -0.4 & $\mathrm{C}_{20} \mathrm{H}_{30} \mathrm{O}_{12}$ & Forsythoside E & $\begin{array}{c}\text { 461.1664[M-H]-, } \\
\text { 315.1104[M-H-Rha]-, } \\
\text { 135.0445[M-H-Rha- } \\
\left.\text { Glc- } \mathrm{H}_{2} \mathrm{O}\right]-\end{array}$ & RG & $\mathrm{P}$ \\
\hline 7 & 3.13 & {$[\mathrm{M}-\mathrm{H}]^{-}$} & 137.0244 & 137.0243 & -0.9 & $\mathrm{C}_{7} \mathrm{H}_{6} \mathrm{O}_{3}$ & p-Hydroxybenzoicacid & $\begin{array}{c}137.0241[\mathrm{M}-\mathrm{H}]-, \\
119.0142\left[\mathrm{M}-\mathrm{H}-\mathrm{H}_{2} \mathrm{O}\right]-\end{array}$ & LC & $\mathrm{P}$ \\
\hline 8 & 3.77 & {$\left[\mathrm{M}+\mathrm{HCOO}^{-}\right.$} & 533.1512 & 533.1517 & 0.9 & $\mathrm{C}_{21} \mathrm{H}_{28} \mathrm{O}_{13}$ & $\begin{array}{c}\text { Lycibarbarphenylpropanoid } \\
\text { A }\end{array}$ & $\begin{array}{c}\text { 487.1468[M-H]-, } \\
163.0396[\mathrm{M}-\mathrm{H}-2 \mathrm{Glc}]- \\
119.0500[\mathrm{M}-\mathrm{H}-2 \mathrm{Glc}- \\
\left.\mathrm{CO}_{2}\right]-\end{array}$ & LB & \\
\hline 9 & 5.34 & {$[\mathrm{M}+\mathrm{HCOO}]^{-}$} & 167.0350 & 167.0348 & -0.8 & $\mathrm{C}_{7} \mathrm{H}_{6} \mathrm{O}_{2}$ & Benzoic acid & $\begin{array}{c}167.0357[\mathrm{M}+\mathrm{HCOO}]- \\
123.0450[\mathrm{M}+\mathrm{HCOO}- \\
\left.\mathrm{CO}_{2}\right]-\end{array}$ & $\mathrm{RP}$ & \\
\hline 10 & 5.50 & {$[\mathrm{M}-\mathrm{H}]^{-}$} & 163.0401 & 163.0401 & 0.5 & $\mathrm{C}_{9} \mathrm{H}_{8} \mathrm{O}_{3}$ & p-Coumaric acid & $\begin{array}{c}163.0395[\mathrm{M}-\mathrm{H}]- \\
119.0499\left[\mathrm{M}-\mathrm{H}-\mathrm{CO}_{2}\right]-\end{array}$ & AS & $\mathrm{P}$ \\
\hline $11 *$ & 5.53 & {$[\mathrm{M}-\mathrm{H}]^{-}$} & 367.1035 & 367.1036 & 0.3 & $\mathrm{C}_{17} \mathrm{H}_{20} \mathrm{O}_{9}$ & 3-O-Feruloylquinic acid & $\begin{array}{c}193.0503[\mathrm{M}-\mathrm{H}-\mathrm{Q} u i n i c \\
\text { acid]-, } 191.0566[\mathrm{M}-\mathrm{H}- \\
\left.\text { Quinic acid-H } \mathrm{H}_{2}\right], \\
173.0488[\mathrm{M}-\mathrm{H}-\mathrm{Q} \text { - } \\
\left.\text { acinic }-\mathrm{H}_{2}-\mathrm{H}_{2} \mathrm{O}\right]-, \\
149.0612[\mathrm{M}-\mathrm{H}-\mathrm{Q} \text { - } \\
\left.\text { acinic }-\mathrm{CO}_{2}\right]-, \\
134.0373[\mathrm{M}-\mathrm{H}-\mathrm{Q} \text { uinic } \\
\left.\text { acid- } \mathrm{CO}_{2}-\mathrm{CH}_{3}\right]-\end{array}$ & $\mathrm{AA}$ & \\
\hline 12 & 5.72 & {$[\mathrm{M}-\mathrm{H}]^{-}$} & 345.1555 & 345.1554 & -0.3 & $\mathrm{C}_{16} \mathrm{H}_{26} \mathrm{O}_{8}$ & Rehmapicroside & $\begin{array}{c}345.1166[\mathrm{M}-\mathrm{H}]- \\
183.1012[\mathrm{M}-\mathrm{H}-\mathrm{Glc}]-\end{array}$ & RG & $\mathrm{P}$ \\
\hline 13 & 7.85 & {$\left[\mathrm{M}+\mathrm{HCOO}^{-}\right.$} & 533.0937 & 533.0942 & 1 & $\mathrm{C}_{24} \mathrm{H}_{22} \mathrm{O}_{14}$ & $\begin{array}{l}\text { Luteolin-7-O-(6-O-malonyl- } \\
\quad \beta \text {-D-glucoside) }\end{array}$ & $\begin{array}{c}\text { 533.1282[M+HCOO }]- \\
487.1433[\mathrm{M}-\mathrm{H}]- \\
443.2878\left[\mathrm{M}-\mathrm{H}-\mathrm{CO}_{2}\right]-\end{array}$ & $\mathrm{CM}$ & \\
\hline $14^{*}$ & 8.90 & {$[\mathrm{M}-\mathrm{H}]^{-}$} & 223.0976 & 223.0976 & -0.1 & $\mathrm{C}_{12} \mathrm{H}_{16} \mathrm{O}_{4}$ & Senkyunolide H & $\begin{array}{c}223.0244[\mathrm{M}-\mathrm{H}]- \\
207.9998\left[\mathrm{M}-\mathrm{CH}_{3}\right]- \\
179.1067\left[\mathrm{M}-\mathrm{H}-\mathrm{CO}_{2}\right]-\end{array}$ & LC & $\mathrm{P}$ \\
\hline 15 & 9.13 & {$[\mathrm{M}-\mathrm{H}]^{-}$} & 119.0502 & 119.0501 & -1 & $\mathrm{C}_{8} \mathrm{H}_{8} \mathrm{O}$ & 1-Phenyl-ethanone & $\begin{array}{c}119.0504[\mathrm{M}-\mathrm{H}]- \\
101.9300\left[\mathrm{M}-\mathrm{H}-\mathrm{H}_{2} \mathrm{O}\right]-\end{array}$ & AS & \\
\hline 16 & 10.72 & {$[\mathrm{M}-\mathrm{H}]^{-}$} & 387.1661 & 387.1662 & 0.4 & $\mathrm{C}_{18} \mathrm{H}_{28} \mathrm{O}_{9}$ & Tuberonic acid glucoside & $\begin{array}{c}\text { 387.1659[M-H]-, } \\
207.1028[\mathrm{M}-\mathrm{H}-\mathrm{GlC}- \\
\left.\mathrm{H}_{2} \mathrm{O}\right]-, 163.1133[\mathrm{M}-\mathrm{H}- \\
\left.\text { Glc- } \mathrm{H}_{2} \mathrm{O}-\mathrm{CO}_{2}\right]- \\
119.0341[\mathrm{M}-\mathrm{H}-\mathrm{GlC}- \\
\left.\mathrm{H}_{2} \mathrm{O}-2 \mathrm{CO}_{2}\right]-\end{array}$ & $\mathrm{CM}$ & \\
\hline 17 & 11.74 & {$[\mathrm{M}-\mathrm{H}]^{-}$} & 225.1132 & 225.1133 & 0.2 & $\mathrm{C}_{12} \mathrm{H}_{18} \mathrm{O}_{4}$ & Chuanxiongnolide R2 & $\begin{array}{c}225.1117[\mathrm{M}-\mathrm{H}]-, \\
207.0666\left[\mathrm{M}-\mathrm{H}-\mathrm{H}_{2} \mathrm{O}\right]-\end{array}$ & LC & $\mathrm{P}$ \\
\hline 18 & 13.20 & {$[\mathrm{M}-\mathrm{H}]^{-}$} & 479.1559 & 479.1555 & -0.7 & $\mathrm{C}_{23} \mathrm{H}_{28} \mathrm{O}_{11}$ & Paeoniflorin & $\begin{array}{c}327.1070[\mathrm{M}-\mathrm{H}- \\
\left.\mathrm{C}_{7} \mathrm{H}_{6} \mathrm{O}_{2}\right]- \\
121.0295[\mathrm{M}-\mathrm{H}- \\
\left.\mathrm{C}_{16} \mathrm{H}_{22} \mathrm{O}_{9}\right]-\end{array}$ & $\mathrm{RP}$ & $\mathrm{P}$ \\
\hline 19 & 13.21 & {$[\mathrm{M}+\mathrm{H}]^{+}$} & 301.1070 & 301.1074 & 1.2 & $\mathrm{C}_{17} \mathrm{H}_{16} \mathrm{O}_{5}$ & $\begin{array}{l}\text { (3R)-5,7-Dihydroxy-6- } \\
\text { methyl-3-(4'- }\end{array}$ & $\begin{array}{c}283.1127[\mathrm{M}+\mathrm{H}- \\
\left.\mathrm{H}_{2} \mathrm{O}\right]+\end{array}$ & $\mathrm{PO}$ & $\mathrm{P}$ \\
\hline
\end{tabular}




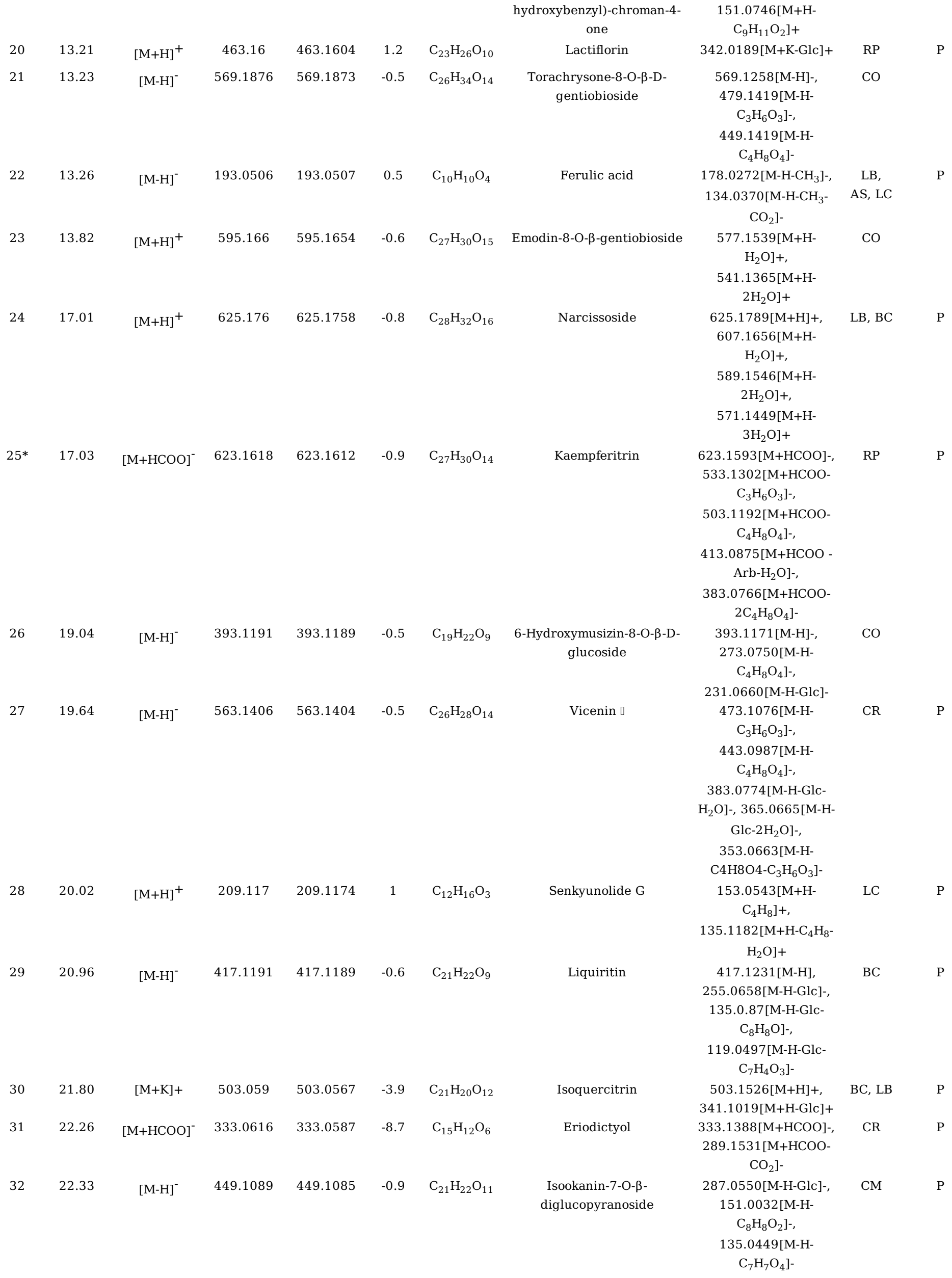




\begin{tabular}{|c|c|c|c|c|c|c|c|c|c|}
\hline 33 & 24.67 & {$[\mathrm{M}-\mathrm{H}]^{-}$} & 328.119 & 328.1189 & -0.6 & $\mathrm{C}_{18} \mathrm{H}_{19} \mathrm{NO}_{5}$ & $\mathrm{~N}$-trans-feruloyloctopamine & $310.1071\left[\mathrm{M}-\mathrm{H}-\mathrm{H}_{2} \mathrm{O}\right]-$ & $\mathrm{PO}$ \\
\hline $34^{*}$ & 24.87 & {$[\mathrm{M}+\mathrm{H}]^{+}$} & 303.05 & 303.0501 & 0.7 & $\mathrm{C}_{15} \mathrm{H}_{10} \mathrm{O}_{7}$ & Quercetin & $\begin{array}{c}303.0512[\mathrm{M}+\mathrm{H}]+ \\
257.0466\left[\mathrm{M}+\mathrm{H}-\mathrm{H}_{2} \mathrm{O}-\right. \\
\mathrm{CO}]+ \\
229.0491\left[\mathrm{M}+\mathrm{H}-\mathrm{H}_{2} \mathrm{O}-\right. \\
2 \mathrm{CO}]+ \\
201.0544\left[\mathrm{M}+\mathrm{H}-\mathrm{H}_{2} \mathrm{O}-\right. \\
3 \mathrm{CO}]+ \\
153.0188[\mathrm{M}+\mathrm{H}- \\
\left.\mathrm{C}_{8} \mathrm{H}_{6} \mathrm{O}_{3}\right]+ \\
137.0244\left[\mathrm{M}+\mathrm{H}-\mathrm{H}_{2} \mathrm{O}-\right. \\
\left.\mathrm{C}_{8} \mathrm{H}_{6} \mathrm{O}_{3}\right]+\end{array}$ & LB \\
\hline $35^{*}$ & 24.89 & {$[\mathrm{M}-\mathrm{H}]^{-}$} & 609.1461 & 609.145 & -1.8 & $\mathrm{C}_{27} \mathrm{H}_{30} \mathrm{O}_{16}$ & Rutin & $\begin{array}{c}\text { 609.1426[M-H]- } \\
\text { 301.0340[M-H-Arb- } \\
\text { Glc]- }\end{array}$ & $\mathrm{BC}$ \\
\hline 36 & 24.90 & {$[\mathrm{M}+\mathrm{H}]^{+}$} & 611.161 & 611.1601 & -1 & $\mathrm{C}_{27} \mathrm{H}_{30} \mathrm{O}_{16}$ & $\begin{array}{c}\text { Kaempferol 3,7-O-di- } \beta \text {-D- } \\
\text { glucopyranside }\end{array}$ & $\begin{array}{c}611.1826[\mathrm{M}+\mathrm{H}]+ \\
303.0513[\mathrm{M}+\mathrm{H}-\mathrm{Glc}- \\
\text { Arb]+ }\end{array}$ & $\mathrm{RP}$ \\
\hline 37 & 25.21 & {$[\mathrm{M}-\mathrm{H}]^{-}$} & 461.0725 & 461.0721 & -1 & $\mathrm{C}_{21} \mathrm{H}_{18} \mathrm{O}_{12}$ & Luteolin-7-O-glucuronide & $\begin{array}{c}461.0720[\mathrm{M}-\mathrm{H}]- \\
285.0389[\mathrm{M}-\mathrm{H}- \\
\left.\mathrm{C}_{9} \mathrm{H}_{8} \mathrm{O}_{6}\right]-\end{array}$ & $\mathrm{CM}$ \\
\hline 38 & 26.49 & {$[\mathrm{M}-\mathrm{H}]^{-}$} & 447.0933 & 447.0928 & -1.1 & $\mathrm{C}_{21} \mathrm{H}_{20} \mathrm{O}_{11}$ & Luteoloside & $\begin{array}{c}\text { 447.0921[M-H]-, } \\
\text { 285.0396[M-H-Glc]- }\end{array}$ & $\mathrm{CM}$ \\
\hline 39 & 26.52 & {$[\mathrm{M}+\mathrm{H}]^{+}$} & 287.055 & 287.0552 & 0.8 & $\mathrm{C}_{15} \mathrm{H}_{10} \mathrm{O}_{6}$ & Alaternin & $\begin{array}{c}287.0553[\mathrm{M}+\mathrm{H}]+ \\
241.0492\left[\mathrm{M}+\mathrm{H}-\mathrm{H}_{2} \mathrm{O}-\right. \\
\mathrm{CO}]+ \\
151.0191[\mathrm{M}+\mathrm{H}- \\
\left.\mathrm{C}_{8} \mathrm{H}_{6} \mathrm{O}_{2}-\mathrm{H}_{2}\right]\end{array}$ & $\mathrm{CO}$ \\
\hline 40 & 26.79 & {$[\mathrm{M}-\mathrm{H}]^{-}$} & 785.251 & 785.2502 & -1 & $\mathrm{C}_{35} \mathrm{H}_{46} \mathrm{O}_{20}$ & Echinacoside & $\begin{array}{c}\text { 785.2497[M-H]-, } \\
\text { 623.21289[M-H-Glc]- }\end{array}$ & RG \\
\hline 41 & 27.85 & {$[\mathrm{M}-\mathrm{H}]^{-}$} & 893.2932 & 893.2925 & -0.8 & $\mathrm{C}_{38} \mathrm{H}_{54} \mathrm{O}_{24}$ & $\begin{array}{l}\text { Torachrysone } \\
\text { tetraglucoside }\end{array}$ & $\begin{array}{c}\text { 893.2927[M-H]-, } \\
245.0819[\mathrm{M}-\mathrm{H}-4 \mathrm{Glc}]-\end{array}$ & $\mathrm{CO}$ \\
\hline 42 & 28.53 & {$[\mathrm{M}-\mathrm{H}]^{-}$} & 187.0976 & 187.0974 & -0.9 & $\mathrm{C}_{9} \mathrm{H}_{16} \mathrm{O}_{4}$ & Anchoicacid & $\begin{array}{c}187.0973[\mathrm{M}-\mathrm{H}]- \\
169.0873\left[\mathrm{M}-\mathrm{H}-\mathrm{H}_{2} \mathrm{O}\right]- \\
143.1072\left[\mathrm{M}-\mathrm{H}-\mathrm{CO}_{2}\right]- \\
125.0971\left[\mathrm{M}-\mathrm{H}^{-} \mathrm{CO}_{2}-\right. \\
\left.\mathrm{H}_{2} \mathrm{O}\right]-\end{array}$ & AS \\
\hline $43 *$ & 28.71 & {$[\mathrm{M}+\mathrm{Na}]+$} & 247.094 & 247.0938 & -0.9 & $\mathrm{C}_{12} \mathrm{H}_{16} \mathrm{O}_{4}$ & Senkyunolide I & $247.0944[\mathrm{M}+\mathrm{H}]+$ & AS \\
\hline 44 & 29.52 & {$[\mathrm{M}-\mathrm{H}]^{-}$} & 627.1931 & 627.1924 & -1 & $\mathrm{C}_{28} \mathrm{H}_{36} \mathrm{O}_{16}$ & Cassialactone gentiobioside & $\begin{array}{c}\text { 627.1943[M-H]-, } \\
\text { 303.0867[M-H-2Glc]-, } \\
259.0975[\mathrm{M}-\mathrm{H}-2 \mathrm{Glc}- \\
\left.\mathrm{CO}_{2}\right]-\end{array}$ & $\mathrm{CO}$ \\
\hline 45 & 30.42 & {$[\mathrm{M}-\mathrm{H}]^{-}$} & 251.0561 & 251.0559 & -0.8 & $\mathrm{C}_{12} \mathrm{H}_{12} \mathrm{O}_{6}$ & $\begin{array}{c}\text { 3-(4-Hydroxy-3-methoxy- } \\
\text { phenyl)-acrylic acid carbox- } \\
\text { ymethyl ester }\end{array}$ & $\begin{array}{c}251.0554[\mathrm{M}-\mathrm{H}]- \\
233.0444\left[\mathrm{M}-\mathrm{H}-\mathrm{H}_{2} \mathrm{O}\right]- \\
207.0666\left[\mathrm{M}-\mathrm{H}-\mathrm{CO}_{2}\right]-\end{array}$ & $\mathrm{PO}$ \\
\hline 46 & 30.67 & {$[\mathrm{M}-\mathrm{H}]^{-}$} & 799.2666 & 799.2659 & -0.9 & $\mathrm{C}_{36} \mathrm{H}_{48} \mathrm{O}_{20}$ & Jionoside A1 & $\begin{array}{c}\text { 799.2662[M-H]- } \\
623.2191[\mathrm{M}-\mathrm{H}- \\
\left.\mathrm{C}_{10} \mathrm{H}_{10} \mathrm{O}_{3}\right]- \\
605.2081[\mathrm{M}-\mathrm{H}- \\
\left.\mathrm{C}_{10} \mathrm{H}_{10} \mathrm{O}_{3}-\mathrm{H}_{2} \mathrm{O}\right]-\end{array}$ & RG \\
\hline 47 & 30.75 & {$[\mathrm{M}-\mathrm{H}]^{-}$} & 271.0612 & 271.0611 & -0.2 & $\mathrm{C}_{15} \mathrm{H}_{12} \mathrm{O}_{5}$ & Naringenin chalcone & $\begin{array}{c}271.0608[\mathrm{M}-\mathrm{H}]- \\
256.0374\left[\mathrm{M}-\mathrm{H}-\mathrm{CH}_{3}\right]- \\
228.0417\left[\mathrm{M}-\mathrm{H}-\mathrm{CH}_{3}-\right. \\
\left.\mathrm{CO}_{2}\right]-\end{array}$ & $\mathrm{CR}$ \\
\hline 48 & 32.33 & {$[\mathrm{M}-\mathrm{H}]^{-}$} & 515.1195 & 515.1189 & -1.2 & $\mathrm{C}_{25} \mathrm{H}_{24} \mathrm{O}_{12}$ & Isochlorogenic acid B & $\begin{array}{c}515.1168[\mathrm{M}-\mathrm{H}]- \\
353.0859[\mathrm{M}-\mathrm{H}- \\
\left.\mathrm{C}_{9} \mathrm{H}_{6} \mathrm{O}_{3}\right]- \\
335.0768[\mathrm{M}-\mathrm{H}- \\
\left.\mathrm{C}_{9} \mathrm{H}_{6} \mathrm{O}_{3}-\mathrm{H}_{2} \mathrm{O}\right]- \\
191.0548[\mathrm{M}-\mathrm{H}- \\
\left.2 \mathrm{C}_{9} \mathrm{H}_{6} \mathrm{O}_{3}\right]- \\
173.0447[\mathrm{M}-\mathrm{H}- \\
\left.2 \mathrm{C}_{9} \mathrm{H}_{6} \mathrm{O}_{3}-\mathrm{H}_{2} \mathrm{O}\right]-\end{array}$ & $\begin{array}{l}\mathrm{CM}, \\
\mathrm{BC}\end{array}$ \\
\hline $49 *$ & 32.54 & {$[\mathrm{M}+\mathrm{Cl}]-$} & 615.1486 & 615.1482 & -0.7 & $\mathrm{C}_{27} \mathrm{H}_{32} \mathrm{O}_{14}$ & Naringin & 579.1714[M-H]-, & CR \\
\hline
\end{tabular}


$\mathrm{C}_{16} \mathrm{H}_{14} \mathrm{O}_{6}$

58

37.63

$[\mathrm{M}+\mathrm{H}]^{+}$

611.197

611.196

$-1.7 \quad \mathrm{C}_{28} \mathrm{H}_{34} \mathrm{O}_{15}$

475.088

475.0885
Isovitexin

\section{Vitexin \\ Puerarin}

Senkyunolide E

,4-Dihydroxybenzaldehyde

Acteoside

(+)-Pinocembrin

Hesperetin

5, 7,2',4'-Tetrahydroxyl homoisoflavanone

Hesperidin

iosmetin 7-glucuronide

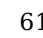

37.99

$[\mathrm{M}+\mathrm{H}]^{+}$

463.12

463.1231

$-0.8$

$\mathrm{C}_{22} \mathrm{H}_{22} \mathrm{O}_{11}$

6

63

$[\mathrm{M}-\mathrm{H}]$

299.056

299.0563

0.5

64

38.41

$[\mathrm{M}+\mathrm{H}]$

609.181

609.1809

$-0.8$

$\mathrm{C}_{28} \mathrm{H}_{32} \mathrm{O}_{15}$

65* $\quad 38.42$

$[\mathrm{M}+\mathrm{H}]$

517.1

517.133

$-$

c]-, $151.0037[\mathrm{M}-\mathrm{H}-$

477.1739[M-H]-

.

]]-, 269.0457[M-H-

1.0598[M+H-Glc]+

CR

BC

LC

AA

RG

$61.1654[\mathrm{M}-\mathrm{H}-$

$$
\text { , }
$$

CR

$$
\left.\mathrm{C}_{8} \mathrm{H}_{8} \mathrm{O}\right]-
$$

$301.0711[\mathrm{M}-\mathrm{H}]-$

CR

P

(3).0475[M-

$151.0038[\mathrm{M}-\mathrm{H}-$

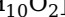

03.0866[M+H]+, PO

$77.0552[\mathrm{M}+\mathrm{H}-$

CR

$\mathrm{CM}$

99.0560[M-H-

$\left.\mathrm{C}_{6} \mathrm{H}_{8} \mathrm{O}_{6}\right]$ -

$284.0235[\mathrm{M}-\mathrm{H}$

$\left.\mathrm{H}_{8} \mathrm{O}_{6}-\mathrm{CH}_{3}\right]$

Glc]+,

$\left.\mathrm{CH}_{3}\right]+$

$\left.\mathrm{CH}_{3}\right]+$

4.0335[M-H-CH 3$]-$

$56.0381\left[\mathrm{M}-\mathrm{H}-\mathrm{CH}_{3}-\right.$

$\mathrm{CH}_{3}-2 \mathrm{CO}$ -

09.1849[M+H]+, $\quad$ CO

163.0395[M+H-

$\left.\mathrm{C}_{16} \mathrm{H}_{16} \mathrm{O}_{8}-\mathrm{H}_{2} \mathrm{O}\right]+$,

$145.0293[\mathrm{M}+\mathrm{H}-$

$\left.\mathrm{C}_{16} \mathrm{H}_{16} \mathrm{O}_{8}-2 \mathrm{H}_{2} \mathrm{O}\right]+$

Chrysophanol

$209.0651\left[\mathrm{M}+\mathrm{H}-\mathrm{H}_{2} \mathrm{O}-\right.$

$$
\mathrm{CO}]+
$$

Prunin

Cassitoroside
435.1298[M+H]+, 273.0765[M+H-Glc]+ $557.1876[\mathrm{M}+\mathrm{H}]+$, 263.0931 [M+H-GlC- 


\begin{tabular}{|c|c|c|c|c|c|c|c|c|}
\hline $69 *$ & 39.80 & {$[\mathrm{M}-\mathrm{H}]^{-}$} & 509.1664 & 509.1618 & -9.2 & $\mathrm{C}_{24} \mathrm{H}_{30} \mathrm{O}_{12}$ & Mudanpioside D & $\begin{array}{c}\mathrm{Arb}]+ \\
\text { 509.1921[M-H]-, } \\
463.2204\left[\mathrm{M}-\mathrm{H}-\mathrm{H}_{2} \mathrm{O}-\right. \\
\text { CO]- }\end{array}$ \\
\hline 70 & 39.90 & {$[\mathrm{M}+\mathrm{H}]^{+}$} & 314.139 & 314.1384 & -0.9 & $\mathrm{C}_{18} \mathrm{H}_{19} \mathrm{NO}_{4}$ & N-trans-Feruloyltyramine & $\begin{array}{c}177.0565[\mathrm{M}+\mathrm{H}- \\
\left.\mathrm{C} 8 \mathrm{H} 8 \mathrm{O}-\mathrm{NH}_{3}\right]+\end{array}$ \\
\hline $71^{*}$ & 39.91 & {$\left[\mathrm{M}+\mathrm{HCOO}^{-}\right.$} & 965.278 & 965.2787 & 0.7 & $\mathrm{C}_{39} \mathrm{H}_{52} \mathrm{O}_{25}$ & Cassiaside B2 & $\begin{array}{c}919.2719[\mathrm{M}-\mathrm{H}]- \\
271.0615[\mathrm{M}-\mathrm{H}-4 \mathrm{Glc}]-\end{array}$ \\
\hline 72 & 39.97 & {$[\mathrm{M}-\mathrm{H}]^{-}$} & 312.1241 & 312.1242 & 0.1 & $\mathrm{C}_{18} \mathrm{H}_{19} \mathrm{NO}_{4}$ & $\mathrm{~N}$-trans-feruloyltyramine & $\begin{array}{c}312.1253[\mathrm{M}-\mathrm{H}]-, \\
297.0999\left[\mathrm{M}-\mathrm{H}-\mathrm{CH}_{3}\right]-, \\
190.0507[\mathrm{M}-\mathrm{H}- \\
\left.\mathrm{C}_{8} \mathrm{H}_{10} \mathrm{O}\right]-, \\
178.0510\left[\mathrm{M}-\mathrm{H}-\mathrm{CH}_{3}-\right. \\
\left.\mathrm{C}_{8} \mathrm{H}_{8} \mathrm{O}\right]-, \\
148.0532\left[\mathrm{M}-\mathrm{H}-\mathrm{CH}_{3}-\right. \\
\left.\mathrm{C}_{8} \mathrm{H}_{8} \mathrm{O}-\mathrm{CH}_{2} \mathrm{O}\right]-\end{array}$ \\
\hline 73 & 41.48 & {$\left[\mathrm{M}+\mathrm{HCOO}^{-}\right.$} & 623.1618 & 623.1617 & 0 & $\mathrm{C}_{27} \mathrm{H}_{30} \mathrm{O}_{14}$ & $\begin{array}{l}\text { Chrysophanol-1-O- } \beta \text { - } \\
\text { gentiobioside }\end{array}$ & $253.0503[\mathrm{M}-\mathrm{H}-2 \mathrm{Glc}]-$ \\
\hline 74 & 41.74 & {$\left[\mathrm{M}+\mathrm{HCOO}^{-}\right.$} & 803.2251 & 803.2253 & 0.2 & $\mathrm{C}_{33} \mathrm{H}_{42} \mathrm{O}_{20}$ & Rubrofusarin triglucoside & $\begin{array}{c}803.4430[\mathrm{M}+\mathrm{HCOO}]- \\
757.4372[\mathrm{M}-\mathrm{H}]- \\
595.3829[\mathrm{M}-\mathrm{H}-\mathrm{Glc}]-\end{array}$ \\
\hline 75 & 41.93 & {$[\mathrm{M}+\mathrm{H}]^{+}$} & 597.181 & 597.1809 & -0.8 & $\mathrm{C}_{27} \mathrm{H}_{32} \mathrm{O}_{15}$ & Emodin-1-O- $\beta$-gentiobioside & $\begin{array}{c}417.1165[\mathrm{M}+\mathrm{H}-\mathrm{Glc}- \\
\left.\mathrm{H}_{2} \mathrm{O}\right]+\end{array}$ \\
\hline 76 & 41.96 & {$[\mathrm{M}-\mathrm{H}]^{-}$} & 595.1668 & 595.1663 & -0.9 & $\mathrm{C}_{27} \mathrm{H}_{32} \mathrm{O}_{15}$ & $\begin{array}{l}\text { Naringenin-6,8-di-C- } \\
\text { glucoside }\end{array}$ & $\begin{array}{c}271.0596[\mathrm{M}-\mathrm{H}-2 \mathrm{Glc}]- \\
256.0372[\mathrm{M}-\mathrm{H}-2 \mathrm{Glc}- \\
\left.\mathrm{CH}_{3}\right]-\end{array}$ \\
\hline 77 & 42.72 & {$[\mathrm{M}-\mathrm{H}]^{-}$} & 637.2138 & 637.2132 & -0.9 & $\mathrm{C}_{30} \mathrm{H}_{38} \mathrm{O}_{15}$ & Jionoside D & $\begin{array}{c}\text { 637.2134[M-H]- } \\
\text { 461.1664[M-H-Arb- } \\
\left.\mathrm{CH}_{2} \mathrm{O}\right]-\end{array}$ \\
\hline 78 & 43.02 & {$[\mathrm{M}+\mathrm{H}]^{+}$} & 771.416 & 771.417 & 1.1 & $\mathrm{C}_{39} \mathrm{H}_{62} \mathrm{O}_{15}$ & Ophiopogonin $\square$ & $\begin{array}{c}771.2822[\mathrm{M}+\mathrm{H}]+ \\
753.4137[\mathrm{M}+\mathrm{H}- \\
\left.\mathrm{H}_{2} \mathrm{O}\right]+ \\
591.3478\left[\mathrm{M}+\mathrm{H}-\mathrm{H}_{2} \mathrm{O}-\right. \\
\mathrm{Glc}]+\end{array}$ \\
\hline 79 & 43.89 & {$[\mathrm{M}+\mathrm{H}]^{+}$} & 1211.569 & 1211.5688 & -0.3 & $\mathrm{C}_{56} \mathrm{H}_{90} \mathrm{O}_{28}$ & Typaspidoside H & $\begin{array}{c}1211.5652[\mathrm{M}+\mathrm{H}]+, \\
593.3691[\mathrm{M}+\mathrm{H}-3 \mathrm{Glc}- \\
\text { Xyl }]+ \\
575.3576[\mathrm{M}+\mathrm{H}-3 G l \mathrm{G}- \\
\left.\text { Xyl- } \mathrm{H}_{2} \mathrm{O}\right]+ \\
557.3466[\mathrm{M}+\mathrm{H}-3 \mathrm{Glc}- \\
\left.\text { Xyl- } 2 \mathrm{H}_{2} \mathrm{O}\right]+\end{array}$ \\
\hline 80 & 43.90 & {$[\mathrm{M}+\mathrm{H}]^{+}$} & 917.474 & 917.4744 & 0.4 & $\mathrm{C}_{45} \mathrm{H}_{72} \mathrm{O}_{19}$ & Polygoside A & $\begin{array}{c}917.4740[\mathrm{M}+\mathrm{H}]+, \\
899.4642[\mathrm{M}+\mathrm{H}- \\
\left.\mathrm{H}_{2} \mathrm{O}\right]+ \\
881.4608[\mathrm{M}+\mathrm{H}- \\
\left.2 \mathrm{H}_{2} \mathrm{O}\right]+ \\
737.4113\left[\mathrm{M}+\mathrm{H}-\mathrm{H}_{2} \mathrm{O}-\right. \\
\mathrm{Glc}]+ \\
719.4014\left[\mathrm{M}+\mathrm{H}-2 \mathrm{H}_{2} \mathrm{O}-\right. \\
\text { Glc }]+ \\
701.3944\left[\mathrm{M}+\mathrm{H}-2 \mathrm{H}_{2} \mathrm{O}-\right. \\
\left.\mathrm{Glc}-\mathrm{H}_{2} \mathrm{O}\right]+, 593.3722 \\
{[\mathrm{M}+\mathrm{H}-\mathrm{Glc}-\mathrm{Glc}]+} \\
429.3003[\mathrm{M}+\mathrm{H}-3 \mathrm{Glc}- \\
\left.\mathrm{H}_{2}\right]+, 411.2900[\mathrm{M}+\mathrm{H}- \\
\left.3 \mathrm{Glc}-\mathrm{H}_{2}-\mathrm{H}_{2} \mathrm{O}\right] \\
393.2793[\mathrm{M}+\mathrm{H}-3 \mathrm{Glc}- \\
\left.\mathrm{H}_{2}-2 \mathrm{H}_{2} \mathrm{O}\right]\end{array}$ \\
\hline 81 & 43.93 & {$[\mathrm{M}-\mathrm{H}]^{-}$} & 1079.528 & 1079.5263 & -1.6 & $\mathrm{C}_{51} \mathrm{H}_{84} \mathrm{O}_{24}$ & $\begin{array}{l}\text { (25S)-26-O-( } \beta \text {-D- } \\
\text { glucopyranosyl)-furost-5- } \\
\text { en3 } 3,22 \alpha, 26 \text {-triol 3-O- } \beta \text {-D- } \\
\text { glucopyranosyl- }(1 \rightarrow 2)-\beta-D- \\
\text { glucopyranosyl- }(1 \rightarrow 4)-\beta-D- \\
\text { gluco-pyranoside }\end{array}$ & $\begin{array}{c}1079.5283[\mathrm{M}-\mathrm{H}]-, \\
1061.5114[\mathrm{M}-\mathrm{H}- \\
\left.\mathrm{H}_{2} \mathrm{O}\right]-,, 737.4175[\mathrm{M}-\mathrm{H}- \\
2 \mathrm{Glc}]-, \quad 575.3614[\mathrm{M}- \\
\text { H-3Glc]-, } \\
557.3412[\mathrm{M}-\mathrm{H}-3 \mathrm{Glc}- \\
\left.\mathrm{H}_{2} \mathrm{O}\right]-, \quad 395.2946[\mathrm{M}-\mathrm{H}-\end{array}$ \\
\hline
\end{tabular}


4 Glc- $\left.\mathrm{H}_{2} \mathrm{O}\right]-$,

413.3060[M-H-4Glc-

$$
\left.\mathrm{H}_{2} \mathrm{O}\right]-
$$

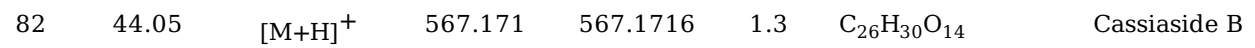

$417.1195[\mathrm{M}+\mathrm{H}-\mathrm{Xyl}-$

$\mathrm{CO}$

P

$\left.\mathrm{H}_{2} \mathrm{O}\right]+$

273.0756[M+H-Xyl-

Glc]+

\begin{tabular}{|c|c|c|c|c|c|c|c|}
\hline 83 & 44.54 & {$[\mathrm{M}+\mathrm{HCOO}]^{-}$} & 331.0823 & 331.0804 & -5.9 & $\mathrm{C}_{16} \mathrm{H}_{14} \mathrm{O}_{5}$ & Isosakuranetin \\
\hline 84 & 44.54 & {$[\mathrm{M}+\mathrm{H}]^{+}$} & 595.202 & 595.2015 & -1 & $\mathrm{C}_{28} \mathrm{H}_{34} \mathrm{O}_{14}$ & Poncirin \\
\hline 85 & 44.55 & {$[\mathrm{M}+\mathrm{H}]^{+}$} & 287.091 & 287.0919 & 1.7 & $\mathrm{C}_{16} \mathrm{H}_{14} \mathrm{O}_{5}$ & $\begin{array}{l}\text { 5,7,4'-Trihydroxyl } \\
\text { homoisoflavanone }\end{array}$ \\
\hline 86 & 44.86 & {$[\mathrm{M}+\mathrm{H}]^{+}$} & 475.123 & 475.123 & -1 & $\mathrm{C}_{23} \mathrm{H}_{22} \mathrm{O}_{11}$ & $\begin{array}{l}\text { Apigenin 7-O- } \\
\text { acetylglucoside }\end{array}$ \\
\hline 87 & 44.92 & {$[\mathrm{M}+\mathrm{H}]^{+}$} & 447.129 & 447.1273 & -2.8 & $\mathrm{C}_{22} \mathrm{H}_{22} \mathrm{O}_{10}$ & Acacetin-7-O-galactoside \\
\hline
\end{tabular}

316.0577[M-H-CH$]-, \quad \mathrm{CR} \quad \mathrm{P}$

$298.0483\left[\mathrm{M}-\mathrm{H}-\mathrm{CH}_{3}-\right.$

$\mathrm{CO}]-$

449.1397[M+H- $\quad$ CR $\quad$ P Rha]+,

287.0904[M+H-Rha$\mathrm{Glc}]+$

287.0923[M+H]+, $\quad$ PO $153.0190[\mathrm{M}+\mathrm{H}-$

$\left.\mathrm{C}_{8} \mathrm{H}_{8} \mathrm{O}\right]+$

475.1240[M+H]+, $\quad$ CM

271.0595[M+H-

$\left.\mathrm{C}_{8} \mathrm{H}_{12} \mathrm{O}_{6}\right]+$

285.0753[M+HGlc]+,

$270.0526[\mathrm{M}+\mathrm{H}-\mathrm{GlC}-$

$\left.\mathrm{CH}_{3}\right]+, 242.0575$

[M+H-Glc- $\left.\mathrm{CH}_{3}-\mathrm{CO}\right]+$,

153.0185 [M+H-Glc-

$\left.\mathrm{C}_{9} \mathrm{H}_{8} \mathrm{O}\right]+$

$\begin{array}{llllllll}88 & 44.97 & {[\mathrm{M}-\mathrm{H}]^{-}} & 1195.5753 & 1195.5749 & -0.3 & \mathrm{C}_{56} \mathrm{H}_{92} \mathrm{O}_{27} & \text { Ophiopogonin F }\end{array}$

1195.5726[M-H]-,

739.4273 [M-H-2Glc-

$\mathrm{Xyl}]-, 577.3731[\mathrm{M}-\mathrm{H}-$

2Glc-Xyl-Glc]-

$559.3653[\mathrm{M}-\mathrm{H}-2 \mathrm{GlC}-$

Xyl-Glc- $\left.\mathrm{H}_{2} \mathrm{O}\right]$-,

415.3208[M-H-2GlcXyl-2Glc]-,

397.3106 [M-H-2GlcXyl-2Glc- $\left.\mathrm{H}_{2} \mathrm{O}\right]-$

$89 \quad 45.25 \quad[\mathrm{M}+\mathrm{Cl}]-\quad 219.0066 \quad 219.0066 \quad 0 \quad \mathrm{C}_{8} \mathrm{H}_{8} \mathrm{O}_{5} \quad$ 3-Methoxygallic acid

201.1643[M+Cl-

$$
\left.\mathrm{H}_{2} \mathrm{O}\right]-
$$

$175.1512\left[\mathrm{M}+\mathrm{Cl}-\mathrm{H}_{2} \mathrm{O}-\right.$

$\left.\mathrm{CO}_{2}\right]-$

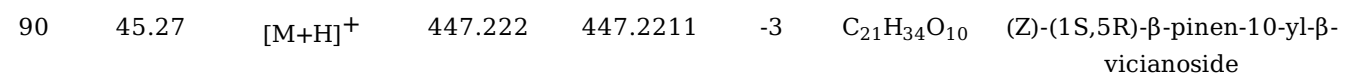

447.2211[M+H]+, $\quad$ RP

$285.0754[\mathrm{M}+\mathrm{H}-$

$\left.\mathrm{C}_{6} \mathrm{H}_{10} \mathrm{O}_{5}\right]+$

$91 \quad 45.54 \quad[\mathrm{M}+\mathrm{H}]^{+} \quad 507.15 \quad 507.149 \quad-1.4 \quad \mathrm{C}_{24} \mathrm{H}_{26} \mathrm{O}_{12} \quad$ 2-Gluco- chrysoobtusin

$345.0960[\mathrm{M}+\mathrm{H}-$

Glc]+,

330.0747 [M+H-GlC-

$\left.\mathrm{CH}_{3}\right]+$,

$312.0632[\mathrm{M}+\mathrm{H}-\mathrm{GlC}-$

$\left.\mathrm{CH}_{3}-\mathrm{H}_{2} \mathrm{O}\right]+$

$92 \quad 45.55 \quad[\mathrm{M}+\mathrm{HCOO}]^{-} \quad 551.1406 \quad 551.1402 \quad-0.8 \quad \mathrm{C}_{24} \mathrm{H}_{26} \mathrm{O}_{12} \quad$ Obtusin glucoside

$551.2850[\mathrm{M}+\mathrm{HCOO}]-, \quad \mathrm{CO} \quad \mathrm{P}$ $389.1246[\mathrm{M}+\mathrm{HCOO}-$

Glc]-,

374.1044[M+HCOO-

Glc- $\left.\mathrm{CH}_{3}\right]$

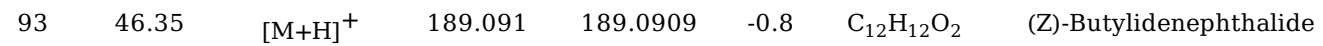

$189.0913[\mathrm{M}+\mathrm{H}]+$

$171.0814[\mathrm{M}+\mathrm{H}-$

$\left.\mathrm{H}_{2} \mathrm{O}\right]+$

$133.0287[\mathrm{M}+\mathrm{H}-$

$2 \mathrm{CO}]+$

191.1060[M+H]+, AS P

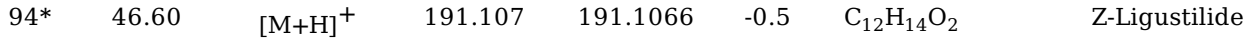




\begin{tabular}{|c|c|c|c|c|c|c|c|c|c|c|}
\hline & & {$[\mathrm{M}-\mathrm{H}]^{-}$} & & & & $\mathrm{C}_{12} \mathrm{H}_{16} \mathrm{O}_{3}$ & & $189.0926\left[\mathrm{M}-\mathrm{H}-\mathrm{H}_{2} \mathrm{O}\right]-$ & & \\
\hline 96 & 48.08 & {$[\mathrm{M}-\mathrm{H}]^{-}$} & 373.1293 & 373.129 & -0.8 & $\mathrm{C}_{20} \mathrm{H}_{22} \mathrm{O}_{7}$ & $\begin{array}{c}5,6,7,3^{\prime}, 4^{\prime}- \\
\text { Pentamethoxyflavanone }\end{array}$ & $\begin{array}{c}373.1265[\mathrm{M}-\mathrm{H}]- \\
358.1054\left[\mathrm{M}-\mathrm{H}-\mathrm{CH}_{3}\right]- \\
343.0803\left[\mathrm{M}-\mathrm{H}-2 \mathrm{CH}_{3}\right]-\end{array}$ & CR & $\mathrm{P}$ \\
\hline 97 & 48.15 & {$[\mathrm{M}+\mathrm{HCOO}]^{-}$} & 373.0929 & 373.0928 & -0.2 & $\mathrm{C}_{18} \mathrm{H}_{16} \mathrm{O}_{6}$ & $\begin{array}{l}\text { 3-Hydroxy-5,7,8- } \\
\text { trimethoxyflavone }\end{array}$ & $\begin{array}{c}373.0922[\mathrm{M}+\mathrm{HCOO}]-, \\
358.0689\left[\mathrm{M}-\mathrm{H}-\mathrm{CH}_{3}\right]- \\
343.0458[\mathrm{M}-\mathrm{H}- \\
\left.2 \mathrm{CH}_{3}\right]-, 328.0233[] \mathrm{M}- \\
\left.\mathrm{H}-3 \mathrm{CH}_{3}\right]-\end{array}$ & CR & \\
\hline 98 & 48.57 & {$[\mathrm{M}+\mathrm{H}]^{+}$} & 315.086 & 315.0867 & 1.2 & $\mathrm{C}_{17} \mathrm{H}_{14} \mathrm{O}_{6}$ & $\begin{array}{c}5,7,3^{\prime}, 4^{\prime}- \\
\text { Tetramethoxyflavone }\end{array}$ & $\begin{array}{c}315.0872[\mathrm{M}+\mathrm{H}]+ \\
300.0638[\mathrm{M}+\mathrm{H}- \\
\left.\mathrm{CH}_{3}\right]+ \\
271.0604[\mathrm{M}+\mathrm{H}- \\
\left.\mathrm{CO}_{2}\right]+\end{array}$ & CR & \\
\hline $99 *$ & 48.64 & {$[\mathrm{M}-\mathrm{H}]^{-}$} & 203.0714 & 203.0712 & -0.9 & $\mathrm{C}_{12} \mathrm{H}_{12} \mathrm{O}_{3}$ & Senkyunolide C & $\begin{array}{c}203.0708[\mathrm{M}-\mathrm{H}]- \\
173.0243[\mathrm{M}-\mathrm{H}- \\
\left.\mathrm{CH}_{2} \mathrm{O}\right]-, \quad 160.0164[\mathrm{M}- \\
\left.\mathrm{H}-\mathrm{H}_{2} \mathrm{O}-\mathrm{CO}\right]-\end{array}$ & AS & \\
\hline 100 & 49.07 & {$[\mathrm{M}-\mathrm{H}]^{-}$} & 373.0929 & 373.0926 & -0.9 & $\mathrm{C}_{19} \mathrm{H}_{18} \mathrm{O}_{8}$ & Casticin & $\begin{array}{c}373.0934[\mathrm{M}-\mathrm{H}] \\
358.0689\left[\mathrm{M}-\mathrm{H}-\mathrm{CH}_{3}\right] \\
343.0453[\mathrm{M}-\mathrm{H}- \\
\left.2 \mathrm{CH}_{3}\right]-, 328.0220[\mathrm{M}- \\
\left.\mathrm{H}-3 \mathrm{CH}_{3}\right]- \\
315.0512[\mathrm{M}-\mathrm{H}-2 \mathrm{CO}]- \\
300.0274[\mathrm{M}-\mathrm{H}-2 \mathrm{CO}- \\
\left.\mathrm{CH}_{3}\right]-\end{array}$ & $\mathrm{CM}$ & \\
\hline 101 & 49.09 & {$[\mathrm{M}+\mathrm{H}]^{+}$} & 331.118 & 331.1176 & 0.0 & $\mathrm{C}_{18} \mathrm{H}_{18} \mathrm{O}_{6}$ & $\begin{array}{c}\text { (3R)-5,7-Dihydroxyl-6- } \\
\text { methyl-8-methoxyl-3-(4'- } \\
\text { hydroxylbenzyl)-chroman-4- } \\
\text { one }\end{array}$ & $\begin{array}{c}331.1179[\mathrm{M}+\mathrm{H}]+ \\
225.0761[\mathrm{M}+\mathrm{H}- \\
\left.\mathrm{C}_{7} \mathrm{H}_{6} \mathrm{O}\right]+ \\
210.0539[\mathrm{M}+\mathrm{H}- \\
\left.\mathrm{C}_{7} \mathrm{H}_{6} \mathrm{O}-\mathrm{CH}_{3}\right]+ \\
107.0494[\mathrm{M}+\mathrm{H}- \\
\left.\mathrm{C}_{11} \mathrm{H}_{12} \mathrm{O}_{5}\right]+\end{array}$ & $\mathrm{PO}$ & \\
\hline 102 & 49.10 & {$[\mathrm{M}+\mathrm{Na}]+$} & 427.136 & 427.1369 & 1.2 & $\mathrm{C}_{21} \mathrm{H}_{24} \mathrm{O}_{8}$ & $\begin{array}{c}5,6,7,8,3^{\prime}, 4^{\prime}- \\
\text { Hexamethoxyflavanone }\end{array}$ & $\begin{array}{c}427.1381[\mathrm{M}+\mathrm{Na}]+ \\
412.1150[\mathrm{M}+\mathrm{Na}- \\
\left.\mathrm{CH}_{3}\right]+ \\
397.0894[\mathrm{M}+\mathrm{Na}- \\
\left.2 \mathrm{CH}_{3}\right] \\
381.0973[\mathrm{M}+\mathrm{Na}-\mathrm{CO}- \\
\left.\mathrm{H}_{2} \mathrm{O}\right] \\
263.0543[\mathrm{M}+\mathrm{Na}- \\
\left.\mathrm{C}_{10} \mathrm{H}_{12} \mathrm{O}_{2}\right] \\
248.0283[\mathrm{M}+\mathrm{Na}- \\
\left.\mathrm{C}_{10} \mathrm{H}_{12} \mathrm{O}_{2}-\mathrm{CH}_{3}\right] \\
233.0046[\mathrm{M}+\mathrm{Na}- \\
\left.\mathrm{C}_{10} \mathrm{H}_{12} \mathrm{O}_{2}-2 \mathrm{CH}_{3}\right]\end{array}$ & CR & \\
\hline 103 & 49.25 & {$[\mathrm{M}+\mathrm{H}]^{+}$} & 359.113 & 359.1129 & 1.1 & $\mathrm{C}_{19} \mathrm{H}_{18} \mathrm{O}_{7}$ & $\begin{array}{l}\text { 5-Hydroxy-3,6,7,8- } \\
\text { tetramethoxyflavone }\end{array}$ & $\begin{array}{c}359.1128[\mathrm{M}+\mathrm{H}]+ \\
344.0891[\mathrm{M}+\mathrm{H}- \\
\left.\mathrm{CH}_{3}\right]+ \\
326.0790\left[\mathrm{M}+\mathrm{H}-\mathrm{CH}_{3}-\right. \\
\left.\mathrm{H}_{2} \mathrm{O}\right]+ \\
329.0661[\mathrm{M}+\mathrm{H}- \\
\left.2 \mathrm{CH}_{3}\right]+ \\
315.0871[\mathrm{M}+\mathrm{H}- \\
\left.\mathrm{CO}_{2}\right]+\end{array}$ & CR & $\mathrm{P}$ \\
\hline 104 & 49.31 & {$[\mathrm{M}+\mathrm{H}]^{+}$} & 403.139 & 403.1372 & -3.8 & $\mathrm{C}_{21} \mathrm{H}_{22} \mathrm{O}_{8}$ & $\begin{array}{c}5,6,7,3^{\prime}, 4^{\prime}, 5^{\prime}- \\
\text { Hexamethoxyflavone }\end{array}$ & $\begin{array}{c}403.1355[\mathrm{M}+\mathrm{H}]+ \\
388.1138[\mathrm{M}+\mathrm{H}- \\
\left.\mathrm{CH}_{3}\right]+ \\
373.0892[\mathrm{M}+\mathrm{H}- \\
\left.2 \mathrm{CH}_{3}\right]+ \\
355.0811\left[\mathrm{M}+\mathrm{H}-2 \mathrm{CH}_{3}-\right. \\
\left.\mathrm{H}_{2} \mathrm{O}\right]+\end{array}$ & CR & $\mathrm{P}$ \\
\hline 105 & 49.46 & {$[\mathrm{M}+\mathrm{H}]^{+}$} & 343.118 & 343.1171 & -1.6 & $\mathrm{C}_{19} \mathrm{H}_{18} \mathrm{O}_{6}$ & $\begin{array}{c}5,7,8,4^{\prime}- \\
\text { Tetramethoxyflavone }\end{array}$ & $\begin{array}{c}343.1187[\mathrm{M}+\mathrm{H}]+ \\
328.0945[\mathrm{M}+\mathrm{H}-\end{array}$ & CR & $\mathrm{P}$ \\
\hline
\end{tabular}




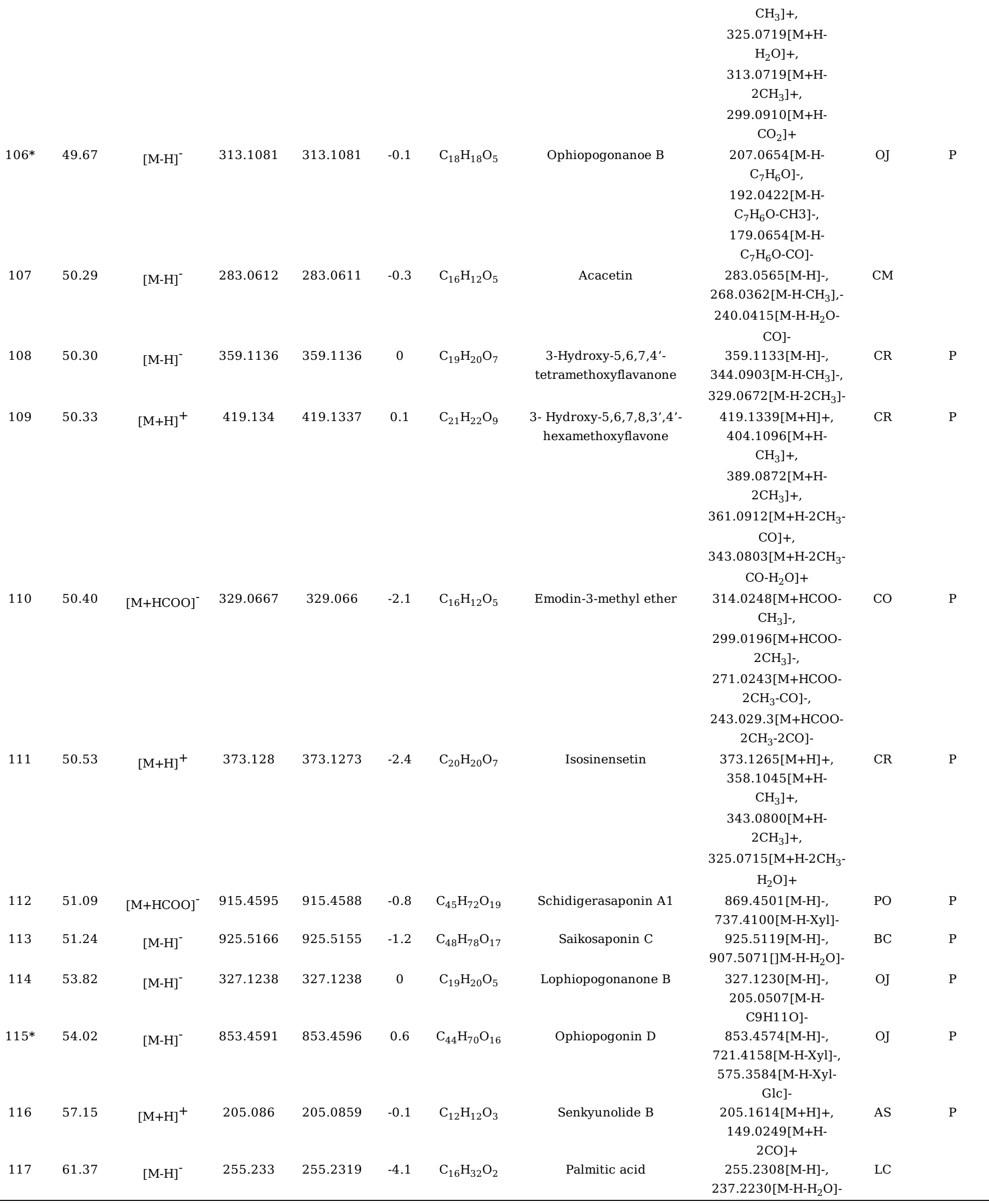

* Identified by comparison with reference standards. P: Prototypes were detected in cynomolgus monkey plasma. Glc: glucose; Rha: rhamnose; Xyl: xylose, Rehmannia glutinosa (RG, Shudihuang), Angelica sinensis (AS, Danggui), Paeonia lactiflora Pall (PL, Baisao), Polygonatum odoratum (PO, Yuzhu), Ophiopogon 
japonicas (OJ, Maidong), Chrysanthemum morifolium (CM, Juhua), Ligusticum chuanxiong (LC, Chuanxiong), Anemone altaica (AA, Jiujiechangpu), and Citrus reticulate (CR, Chenpi), Cassiae Semen (CS, Juemingzi), Lycii Fructus (LF, Gouqizi), and Bupleuri Radix (BR, Chaihu)

\section{Figures}

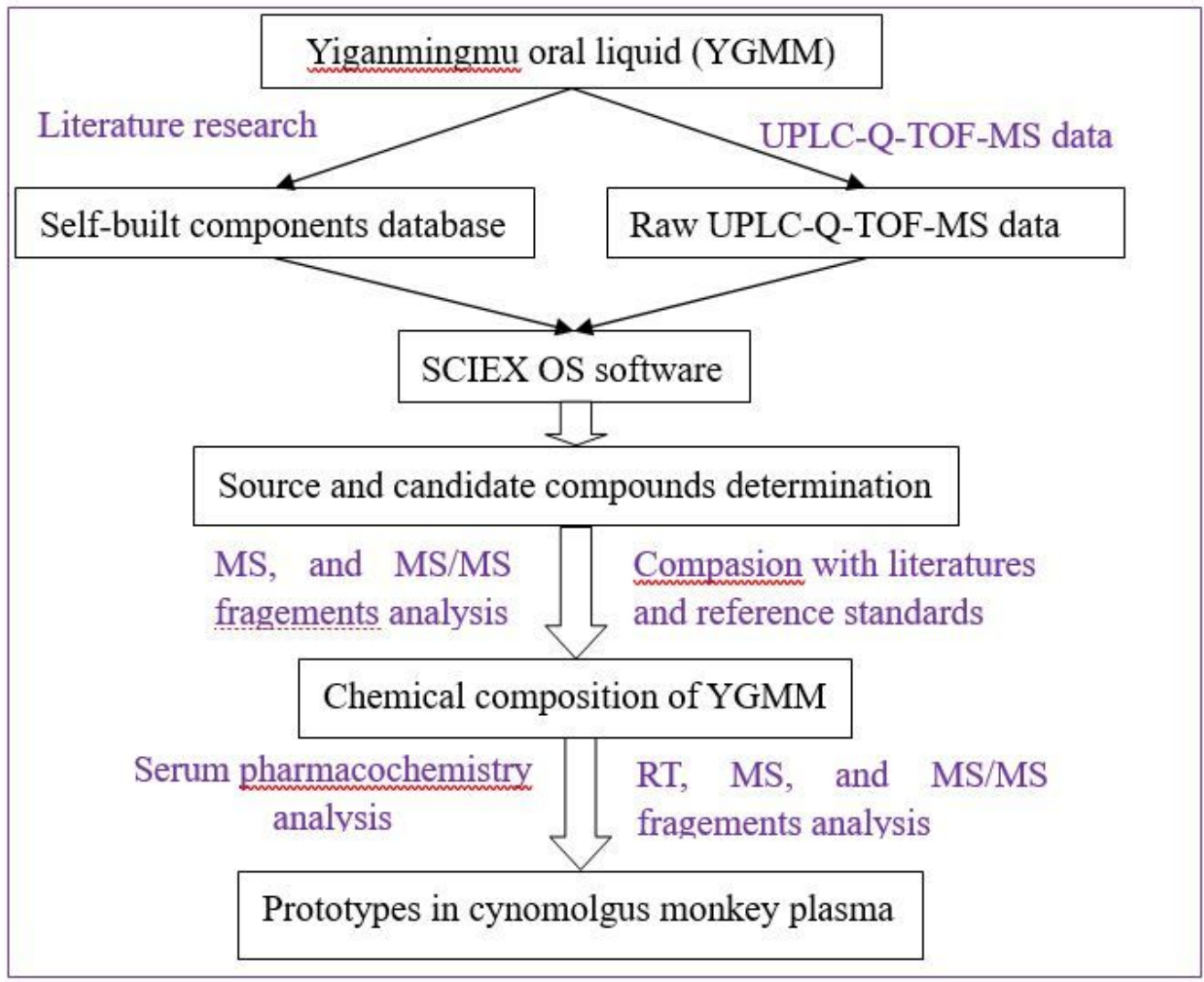

Figure 1

The data analysis strategy for identification of chemical constituents in YGMM and prototypes in cynomolgus monkey plasma 

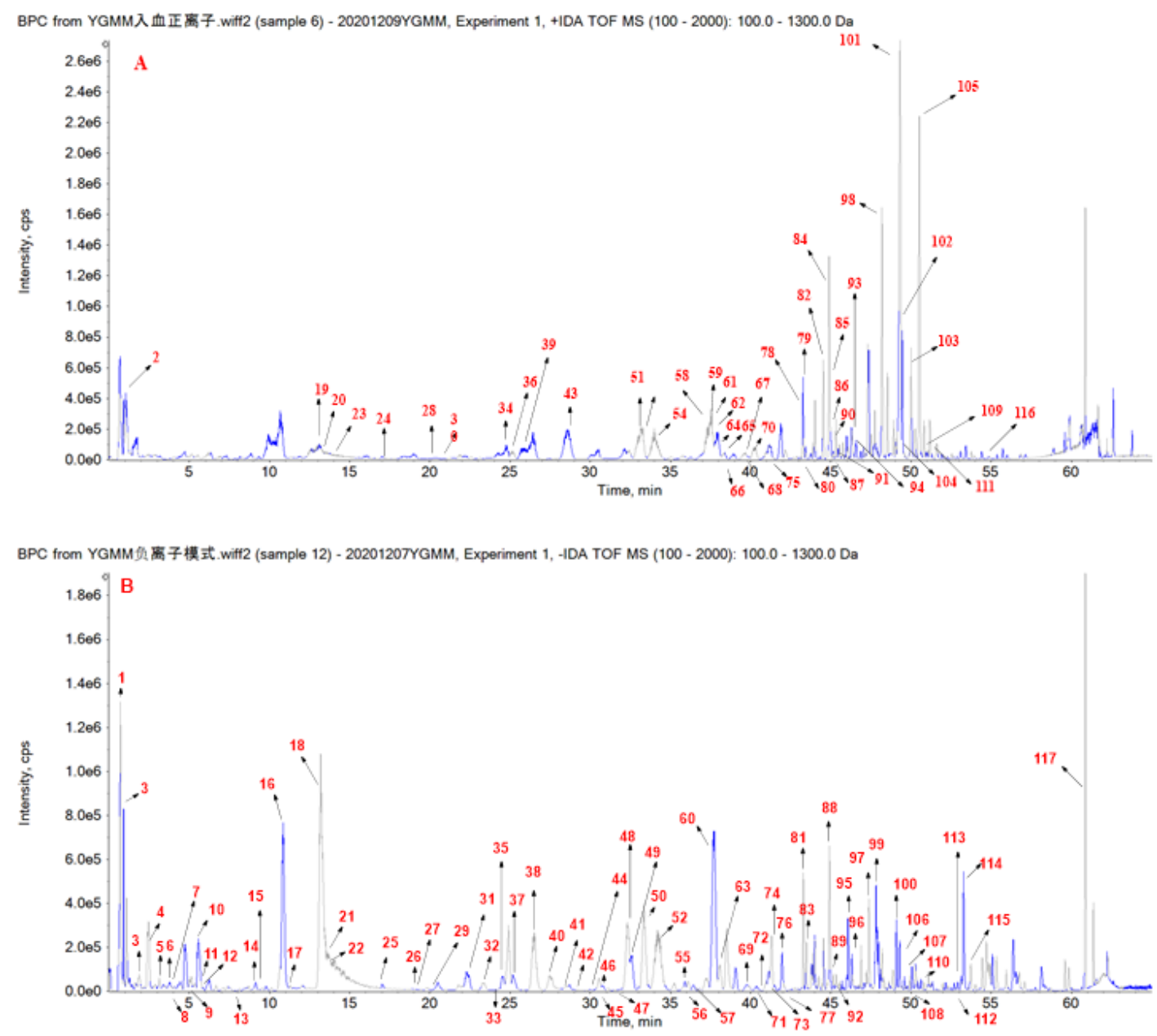

\section{Figure 2}

The BPC of YGMM in positive (A) and negative (B) ion modes. 


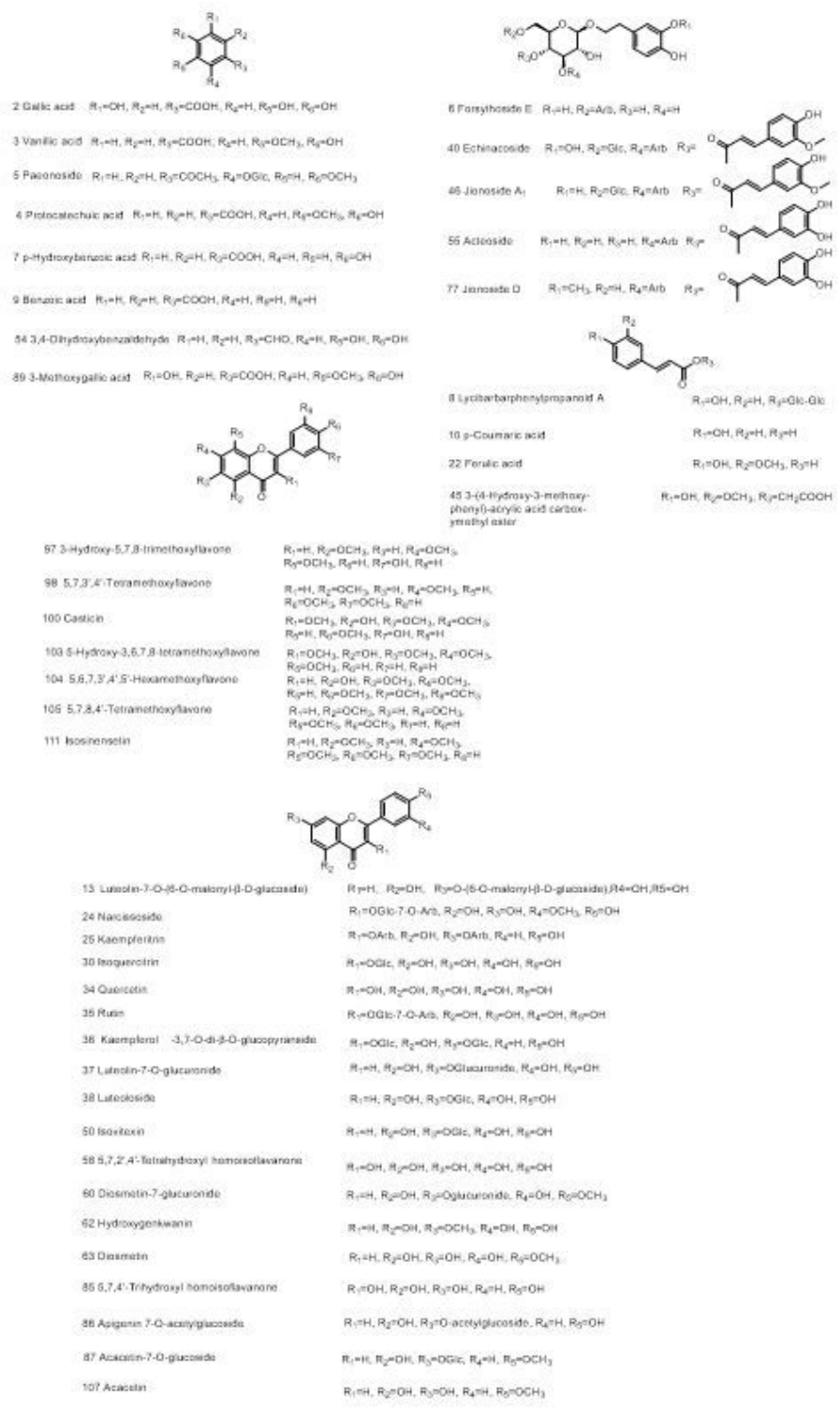

\section{Figure 3}

The chemical structures of main identified constituents in YGMM 


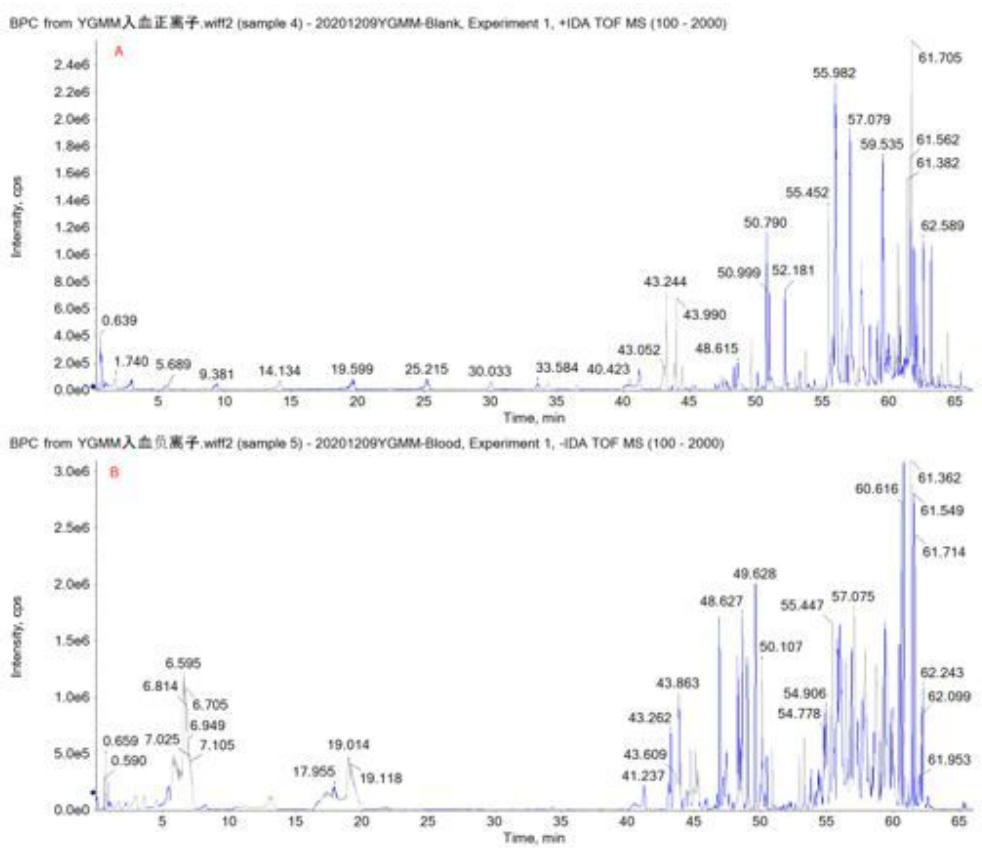

\section{Figure 4}

Drugged cynomolgus monkey plasma in the positive (A) and negative (B) ions mode
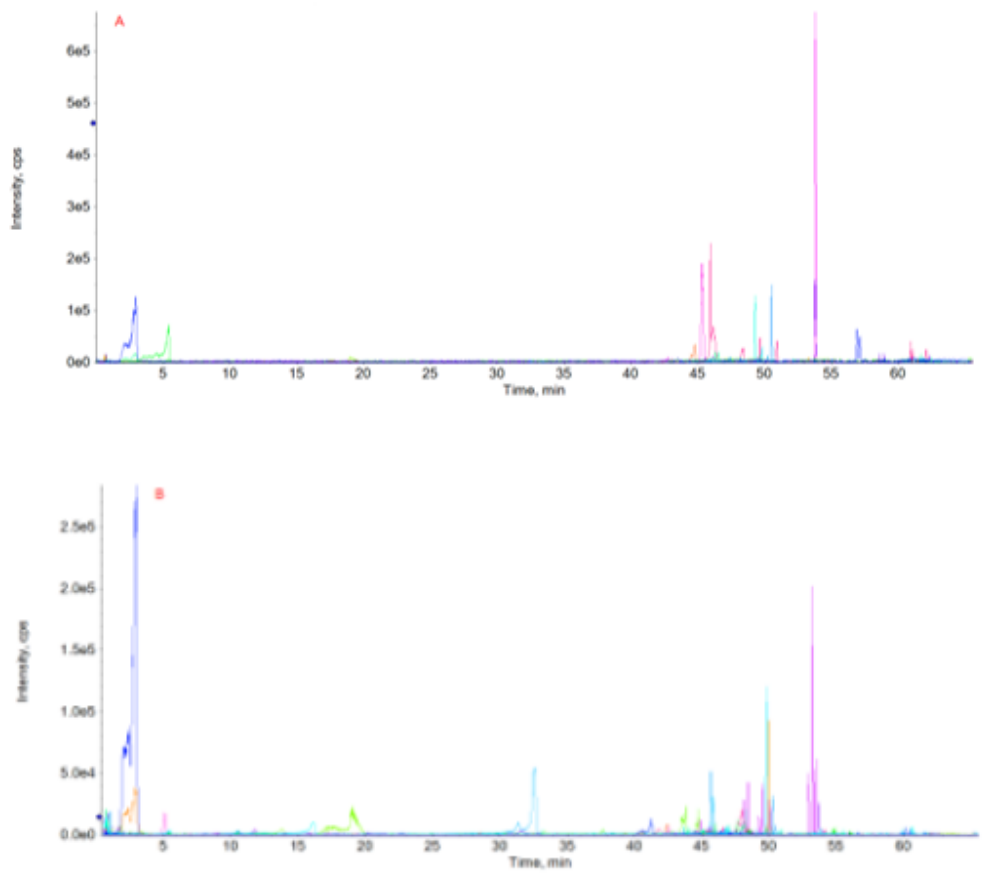

\section{Figure 5}

Extracted ion chromatograms (EICs) of prototypes in drugged biosample in the positive (A) and negative (B) ions mode

\section{Supplementary Files}

This is a list of supplementary files associated with this preprint. Click to download.

- Supplementaryinformation.docx 